Institut für Makroökonomie und Konjunkturforschung Macroeconomic Policy Institute

\title{
Did inequality cause the U.S. financial crisis?
}

\begin{abstract}
In his widely discussed book "Fault Lines" (2010), Raghuram Rajan argues that many U.S. consumers have reacted to the decline in their relative permanent incomes since the early 1980s by reducing saving and increasing debt. This has temporarily kept private consumption and thus aggregate demand and employment high, despite stagnating incomes for many households. But it also contributed to the creation of a credit bubble, which eventually burst, and a large current account deficit in the United States. We place the Rajan hypothesis in the context of competing theories of consumption, and survey the empirical literature on the effects of inequality on household behaviour beyond the largely anecdotal evidence provided in Rajan (2010). We argue that the Rajan hypothesis, supported by the empirical evidence, calls for a renaissance of the relative income hypothesis of consumption.
\end{abstract}

Keywords: Great Recession, income inequality, household debt, consumption theory

JEL classifications: D1, D3, E21, E51, G01 


\title{
Did inequality cause the U.S. financial crisis?*
}

\author{
Till van Treeck \\ Macroeconomic Policy Institute (IMK), Düsseldorf
}

April 2012

\begin{abstract}
In his widely discussed book "Fault Lines" (2010), Raghuram Rajan argues that many U.S. consumers have reacted to the decline in their relative permanent incomes since the early 1980s by reducing saving and increasing debt. This has temporarily kept private consumption and thus aggregate demand and employment high, despite stagnating incomes for many households. But it also contributed to the creation of a credit bubble, which eventually burst, and a large current account deficit in the United States. We place the Rajan hypothesis in the context of competing theories of consumption, and survey the empirical literature on the effects of inequality on household behaviour beyond the largely anecdotal evidence provided in Rajan (2010). We argue that the Rajan hypothesis, supported by the empirical evidence, calls for a renaissance of the relative income hypothesis of consumption.
\end{abstract}

Keywords: Great Recession, income inequality, household debt, consumption theory

JEL classifications: D1, D3, E21, E51, G01

\footnotetext{
* Address for correspondence: Till van Treeck, Macroeconomic Policy Institute (IMK), Hans-Böckler-Straße 39, 40476 Düsseldorf, Germany. Email: Till-van-Treeck@boeckler.de. I thank Eckhard Hein, Ansgar Rannenberg, Simon Sturn, Thomas Theobald, Lukas Tockner and Achim Truger for valuable comments and Benjamin Neuhaus, Katharina Sass and Rory Tews for helpful research assistance. This paper is part of a larger joint project with Simon Sturn (van Treeck and Sturn, forthcoming). Financial support of the International Labour Organization (ILO) is gratefully acknowledged. All errors are mine.
} 


\title{
1 Introduction
}

As noted by The Economist (22/01/2011, p. 11), “[s]everal prominent economists now reckon that inequality was a root cause of the financial crisis.” Indeed, in recent years there has been a proliferation of analyses supporting this view (e.g. UN Commission of Experts, 2009; Stiglitz, 2009; IMF-ILO, 2010; Rajan, 2010; Reich, 2010; Kumhof and Rancière, 2010; Kumhof et al, 2012; Galbraith, 2012; Palley, 2012). The explanation is straightforward: As the benefits of rising aggregate income over the past decades were confined to a rather small group of households at the top of the income distribution, the consumption of the lower and middle income groups was largely financed through rising credit rather than rising incomes. This process was facilitated by government action, both directly through credit promotion policies and indirectly through the deregulation of the financial sector. But with the downturn in the housing market and the sub-prime mortgage crisis starting in 2007, the overindebtedness of the U.S. personal sector became apparent and the debt-financed private demand expansion came to an end. We refer to this line of argument as the "Rajan hypothesis", because of the impetus Rajan’s book “Fault Lines” (2010) has given to the renewed interest in inequality as a macroeconomic risk.

Rajan (2010, p. 9) succinctly summarises his argument as follows:

\begin{abstract}
"[T]he political response to rising inequality - whether carefully planned or an unpremeditated reaction to constituent demands - was to expand lending to households, especially low-income ones. The benefits - growing consumption and more jobs - were immediate, whereas paying the inevitable bill could be postponed into the future. Cynical as it may seem, easy credit has been used as a palliative throughout history by governments that are unable to address the deeper anxieties of the middle class directly. [...] In the United States, the expansion of home ownership - a key element of the American dream - to low and middleincome households was the defensible linchpin for the broader aims of expanding credit and consumption. But when easy money pushed by a deep-pocketed government comes into contact with the profit motive of a sophisticated, competitive, and amoral financial sector, a deep fault line develops.” (Rajan, 2010, p. 9)
\end{abstract}

While Rajan puts a lot of emphasis on government failure and the political economy of income inequality and financial market deregulation, the more important implication of his analysis is the rejection of the conventional theories of consumption, which see no link between the inequality of (permanent) income and aggregate personal consumption, and hence no need for government action stimulating consumption and jobs in response to higher inequality. Moreover, while many recent analyses of the crisis point to the crucial role of deregulated financial markets, asset bubbles and debt accumulation (e.g. Shiller, 2008; Reinhart and 
Rogoff, 2010), “[t]hat does not however seem to be the end of the matter, since inequality could have had an indirect effect in contributing to the asset bubble" (Atkinson and Morelli, 2010, p. 58). Thus, in essence, the Rajan hypothesis posits that given the rise in inequality the credit expansion in the personal sector was both necessary for supporting aggregate demand and employment, and it was unsustainable.

The Rajan hypothesis existed long before Rajan (2010). In his bestseller on the causes of the "Great Crash" of 1929 and the subsequent Great Depression in the United States, John K. Galbraith (1954) mentions "the bad distribution of income" as the first of "five weaknesses [which] seem to have had an especially intimate bearing on the ensuing disaster" (Galbraith, 1954 [1997, pp. 177 et seq.]). Similarly, the former chairman of the Federal Reserve Bank, Marriner S. Eccles, points to the rising inequality and credit-financed consumption during the 1920s when, “as in a poker game where the chips were concentrated in fewer and fewer hands, the other fellows could stay in the game only by borrowing. When their credit ran out, the game stopped” (Eccles, 1951, p. 76). ${ }^{1}$ While these lessons from the Great Depression were largely forgotten, perhaps due to the relatively low inequality during the first three postwar decades, some economists have essentially anticipated the Rajan hypothesis since the 1980s, when inequality started to soar again in the United States (e.g. Pollin, 1988; Palley, 1994, 2002; Frank, 1999, 2007; Boushey and Weller, 2006; Dutt, 2006; Cynamon and Fazzari, 2008; Barba and Pivetti, 2009; Horn et al., 2009).

But many economists either ignored the macroeconomic implications of inequality or explicitly welcomed the increasing availability of personal credit as an efficient market response to a higher demand by households for insurance against a higher dispersion of the transitory component of income (e.g. Greenspan, 1996; Krueger and Perri, 2003, 2006). Theoretically, this lack of attention to inequality seemed justified by the permanent income hypothesis, first formulated by Friedman (1957), which posits that household consumption is unrelated to the inequality of permanent income. However, recent empirical work strongly suggests that the rise in inequality over the past decades has been largely due to the permanent rather than transitory components of income (e.g. Kopczuk et al., 2010). The Rajan hypothesis, which relies on the assumption of a higher inequality in the permanent component of income, is thus of great theoretical importance, and it bears resemblance to the relative income hypothesis (Duesenberry, 1949; Frank, 1985, 2005).

\footnotetext{
${ }^{1}$ See Olney (1991) for an analysis of the expansion of personal credit during the 1920s. See Olney (1999) for an analysis of the link between personal credit and debt and the consumption collapse of 1930. See Kumhof and Rancière (2010) for a discussion of the parallels between the Great Depression and the Great Recession in terms of the link between inequality, household debt, and crisis.
} 
The Rajan hypothesis has triggered a lively debate about inequality in the United States, and the initial reception was controversial (Financial Times, 01/10/2010; The Economist, 22/01/2011). Rajan's critique of government policies that explicitly aimed at promoting lending to low income groups was taken up in the dissenting statement of the Republican members of the government's Financial Crisis Inquiry Commission (FCIC, 2011, p. 486). Some thus saw it as "a Republican narrative” and have taken issue with its underlying political tone, perceived to suggest that "the poor caused the crisis" together with misguided government policies responding to their demands (Johnson, 2011). Yet, the "Democratic" majority group of the FCIC refers especially to Rajan's (2005) earlier critique of the deregulation of the financial system, which was defended at the time by many economists and by the political establishment (FCIC, 2011, p. 17). Palley (2012) is also very critical of Rajan (2010) and argues that "according to Rajan, the only effect of worsened income distribution was to provoke populist meddling. There were no effects regarding creating a shortage of demand, which is part of the Keynesian account of income distribution” (Palley, 2012, p. 120). However, as the quote from the introduction of Rajan (2010, p. 9) shows, the Rajan hypothesis is explicitly macroeconomic. Others have noted the lack of emphasis on the explosion of incomes within the very top (5, or 1 per cent) of the income distribution in Rajan's argument, which focuses on changes in the 90/10 and 90/50 income differentials due to skill-biased technological change. Top inequality in turn may have been driven by political decisions, which were facilitated by the role of the financial industry in lobbying and political party funding (e.g. Hacker and Pierson, 2010), but is also related to the deregulation of the financial markets. Thus, the concomitant rise in inequality and financial fragility may be due to coincidence rather than causality (Krugman, 2010; Atkinson and Morelli, 2010; Acemoglu, 2011).

Recently, however, there seems to be increasing agreement that rising inequality, whatever its precise origins, did play a role in the specific case of the U.S. financial crisis, although it is doubted whether the argument can be universally applied to other countries and crises. Kumhof et al. (2012), building on Kumhof and Rancière (2010) ${ }^{2}$, argue, on the basis of an open economy, dynamic stochastic general equilibrium (DSGE) model, that in advanced, especially Anglo-Saxon, economies with highly developed financial markets, rising inequality has led to a deterioration of savings-investment balances, as the poor and middle class borrowed from the rich and from foreign lenders to finance consumption. This view is supported by results

\footnotetext{
${ }^{2}$ Kumhof and Rancière (2010) present a theoretical dynamic stochastic general equilibrium model (DSGE) where the increase in the top income share leads to higher leverage for the remainder of the population, and eventually triggers a financial and real crisis. The macroeconomic models by Palley (1994) and Dutt (2006) describe essentially similar mechanisms. See Subsection 4.4.
} 
from a panel regression analyses for 18 OECD countries for the period 1968-2008. However, the generality of these results is called into question by the findings of Bordo and Meissner (forthcoming) who estimate a panel of 14 advanced economies for the period 1920-2008 and conclude that while financial crises are typically preceded by credit booms, inequality only occasionally rises during periods of credit expansion. For example, it has been argued that in Germany, private households did not react to falling incomes and increased income dispersion by borrowing more, but by higher precautionary savings, thus contributing to the improvement of the current account since the early 2000s (e.g. Carlin and Soskice, 2007; Fitoussi and Stiglitz, 2009; Bofinger, 2012). Similarly, Atkinson and Morelli (2010, p. 66) conclude from their cross-country empirical analysis that "[o]utside the US, the history of systemic banking crises in different countries around the world does not suggest that either rising or high inequality has been adduced as a significant causal factor.” The Economist (17/3/2012) concludes: “Mr Rajan’s story may work for America’s 2008 crisis. It is not an iron law”.

In this paper, we focus on the United States and summarise the available empirical literature in support of the Rajan hypothesis beyond the largely anecdotal evidence provided in Rajan (2010). ${ }^{3}$ We also discuss some of the criticisms and, indeed, weaknesses in Rajan's own argument. Moreover, we place the Rajan hypothesis in the context of competing theories of consumption and, specifically, a recently growing body of literature that calls for a renaissance of the relative income hypothesis.

The remainder of this paper is structured as follows: Section 2 briefly describes the evolution of income distribution and the composition of aggregate demand in the United States during the past decades. Section 3 shows that the Rajan hypothesis is inconsistent with the influential but largely flawed view that the rise in personal debt prior to the Great Recession responded to the increased demand by households for insuring transitory income shocks. Rather, the Rajan hypothesis can be seen as an application of the relative income hypothesis of consumption, which predicts that households will react to a decline in (permanent) relative incomes by lower saving and higher debt. Section 4 discusses the empirical evidence supportive of the Rajan hypothesis and the relative income model. Section 5 concludes.

\footnotetext{
${ }^{3}$ In van Treeck and Sturn (forthcoming), we also discuss the macroeconomic consequences of changes in the distribution of income in China and Germany, which both experienced pronounced declines in the share of wages and household income in national income, strong increases in personal inequality, rising personal saving rates, weak private consumption demand and strong improvements in the current account before the Great Recession. Specifically, we argue that the ways in which consumers react to changes in relative income depend on such institutional factors as the deepness and regulation of the credit markets, the organisation of the labour market and the education and welfare systems, and the reactivity of monetary and fiscal policy to cyclical unemployment. We conclude that reducing inequality in these countries is crucial for overcoming the global and European current account imbalances and macroeconomic instability over the longer term.
} 


\section{Trends in income distribution and aggregate demand}

The old theories of underconsumption feared that a gradual decline in the wage share in national income would lead to a shortfall of aggregate demand and oversaving due to a lack of purchasing power of the consuming classes (e.g. Malthus, 1820; Hobson, 1909). At first sight at least, nothing could be further from the truth with respect to the macroeconomic trends in the United States before the Great Recession: While the share of labour income in gross domestic income decreased somewhat since the early 1980s, private consumption as a share of GDP increased massively by almost 10 percentage points (Figure 1). This has been accompanied by a deterioration of the trade balance and the current account, especially since the mid1990s (Figure 2). These changes in the composition of aggregate demand were accompanied by rather robust economic growth and low unemployment.

Note that the rise in private consumption as a share of GDP is due entirely to higher nondurable consumption spending, while the ratio of durable consumption to GDP has been flat over time. That is, the rise in the consumption-to-GDP ratio does not reflect increased saving through durables. The increase in the consumption-to-GDP ratio has not been continuous, but there are flat segments especially in the mid-1990s and in the first half of the 2000s. However, the weaker consumption dynamics during that time have been more than compensated for by private investment in housing. Partly as a result of this, household net lending, unlike personal saving, was positive in 1999-2007 (Figure 2). While the government deficit and the corporate financial balance, although highly cyclical, have been at similar levels in the mid-1980s and mid-2000s, the secular decline in the private household balance fully accounts for the weaker current account in the mid-2000s as compared to the mid-1980s.

The explosion of top incomes is certainly the most peculiar aspect of the rise in inequality in the United States. Most strikingly, the increase in the share of top incomes is driven mainly by that within the top 1 per cent, or even the top 0.5 and 0.1 per cent, of all households (Figure 3). This phenomenon is quantitatively very important: While the top 10 per cent account today for almost half of total pre-tax household income, the top 1 per cent alone account for almost one fifth. Moreover, as noted by Piketty and Saez (2006, p. 204), “top executives (the "working rich”) replaced top capital owners (the "rentiers”) at the top of the income hierarchy during the twentieth century.”

But even below the top 10 per cent, the increase in income dispersion has been very substantial in the United States. Although the precise estimates of inequality differ according to 
different data sources, ${ }^{4}$ there is little controversy about the overall trends. Figure 4, based on data from the Current Population Survey (CPS), shows the evolution of hourly wages at the $10^{\text {th }}, 50^{\text {th }}$ and $90^{\text {th }}$ percentiles of the wage distribution for all workers (men and women combined). In the bottom half of the distribution, individual wage inequality has sharply increased in the early 1980s but has remained roughly constant since then. By contrast, wage inequality has steadily increased in the top half of the distribution since the early 1980s. ${ }^{5}$ Note that the increase in inequality has been more pronounced for income than for hourly wages in the upper half of the distribution, partly because high income households receive a larger fraction of their income from capital. By contrast, it was less pronounced for income than for hourly wages at the bottom of the distribution, mainly as a result of government transfers (see Heathcote et al., 2010). Figure 5 shows the rate of growth of real family incomes for two time periods. Real pre-tax income growth (excluding capital gains) has been considerably lower in 1977-2007 as compared to 1947-1977 for all families except for those at the very top. The first period is also referred to as the "Great Convergence" (Goldin and Margo, 1992), as lower and middle incomes have grown faster than top incomes.

\section{The Rajan hypothesis and the relative income hypothe- sis}

\subsection{Why was the problem of inequality ignored for so long?}

The permanent income and life-cycle hypotheses (Friedman, 1957; Modigliani and Brumberg, 1954) posit that aggregate personal saving is unrelated to the distribution of permanent income, while a higher transitory variance of income may lead to higher precautionary saving. Yet, when coupled with the assumption of rational expectations (Hall, 1978), the permanent income hypothesis says that even with a higher variability in the transitory component of income consumption can be smoothed through lending and borrowing in the presence of efficient credit markets. Inspired by this theory, a very influential view up until the Great Recession was the rise in measured inequality reflected mainly a higher dispersion in the transitory components of income, which households could insure against through credit markets. Hence, the idea was not that "easy credit has been been used as a palliative [...] by governments" (Rajan, 2010, p. 39), but "that the structure of the credit markets in an economy is endogenous

\footnotetext{
${ }^{4}$ See Heathcote et al. (2010) for a comparison of different data sets.

5 The rise in wage inequality above the median has been much more pronounced for male workers than for all workers: median hourly male wages are lower in real terms today than in the 1970s. But the gap between middle and bottom wages has increased more strongly for all workers than for male workers because female workers have fared better than male workers in the middle of the distribution but almost equally poorly at the bottom.
} 
and may evolve in response to higher income volatility” (Krueger and Perri, 2006, p. 164). We refer to this view as the Greenspan-Krueger-Perri argument with reference to Greenspan (1996) and Krueger and Perri (2003, 2006). In 1996, Alan Greenspan, then chairman of the Federal Reserve Bank, noted: ${ }^{6}$

"[I]ncome disparities, as measured by Gini coefficients, climbed steadily through $1994[\ldots]$ But $[\ldots]$ there is a surprising difference between trends in the dispersion of holdings of claims to goods and services (that is, income and wealth) and trends in the dispersion of actual consumption. [...] I do not wish to disparage income as a partial antidote to insecurity. Nevertheless, some aspects of economic well-being may be more accurately discerned by examining consumption.” (Greenspan, 1996, p. 176)

The work by Krueger and Perri (2003, 2006), though not the first to investigate the relationship between income and consumption inequality ${ }^{7}$, corresponded to Greenspan's request for research along these lines. Krueger and Perri (2006) construct different measures of consumption using the Interview Survey (IS) of the Consumer Expenditure Survey (CEX) and find that the variance of their preferred measure of logarithmic consumption (nondurables, services, small durables and imputed services from housing and vehicles) has increased by only 5.3 per cent in 1980-2003, whereas the variance of logarithmic income (after-tax labour earnings plus transfers) has increased by 21.4 per cent. Moreover, essentially all of the increase in consumption inequality took place during the 1980s, although it was smaller than the increase in income inequality even during this period. During the 1990s and until 2003, consumption inequality remained essentially flat, according to the data used by Krueger and Perri. Furthermore, Krueger and Perri distinguish between "between-group” and "within-group” inequality. Following Katz and Autor (1999), they regress income and consumption on the following characteristics of the reference person and the spouse (if present): sex, race, years of education, experience, interaction terms between experience and education, dummies for managerial/professional occupation, and region of residence. These characteristics explain about 25 per cent of the cross-sectional variation of income and consumption in 1980. The authors denote the cross-sectional variance explained by these characteristics as "betweengroup” inequality and the residual variance as "within-group” inequality. Based on these definitions, they find that for consumption, the between-group component displays an increase similar in magnitude to that of income. But for the within-group component, the increase in

\footnotetext{
${ }^{6}$ Greenspan also expressed rather different views about the issue of inequality: "This is not the type of thing which a democratic society - a capitalist democratic society - can really accept without addressing” (quoted from Noah, 2010).

${ }^{7}$ See Attanasio et al. (2007) for a survey.
} 
consumption inequality (around 3 per cent) is much smaller than the increase in income inequality (around 16 per cent). They conclude that within-group inequality is mainly transitory or somehow insurable, whereas changes in between-group inequality reflect permanent, or uninsurable, changes in distribution. Finally, based on the finding of a strong correlation between the ratio of unsecured consumer credit to disposable income and the Gini coefficient, the authors conclude that this "may suggest that consumers could, and in fact did, make stronger use of credit markets exactly when they needed to (starting in the mid-1970's), in order to insulate consumption from bigger income fluctuations.” (Krueger and Perri, 2006, p. 187; see also Kruger and Perri, 2003, p. 15). Further analyses with roughly similar results include Blundell et al. (2008), Blundell (2011) and Heathcote et al. (2010), using data from the CEX or from the Panel Study of Income Dynamics (PSID). ${ }^{8}$

These conclusions are, however, far from undisputable for both data and conceptual reasons. As recognised by Krueger and Perri (2003, p. 14) in a footnote, an important concern with the CEX data is that their total does not match up with the NIPA total. The gap between the CEX-IS and NIPA measures of aggregate consumption is disconcertingly large and has been growing considerably over time, from around 20 per cent in the mid-1970s to around 60 per cent in the 2000s (Battistin, 2003; Heathcote et al., 2010, p. 21). In fact, from 1980 to 2005, real per capita consumption has increased by almost 50 per cent, whereas the corresponding CEX measure has remained essentially flat. There do not seem to be any easy explanations for this discrepancy (Slesnick, 1992, 2001; Attanasio et al., 2007). In fact, the CEX measure of aggregate income continues to track the NIPA measure rather well (see Heathcote et al., 2010 for a discussion). Clearly, the very poor quality of the CEX consumption data does not allow any firm conclusions.

A further problem with survey-based studies on the link between income and consumption inequality is that due to the use of top-coded data, the potential effects of rising consumption at the top on the behaviour of all households below the top are not addressed at all by analyses of the Krueger and Perri-type. In principle, it is possible that the explosion of incomes at the top has led to expenditure cascades starting well above the $90^{\text {th }}$ income percentile, while having only small effects on consumption inequality as measured by the 90/50 or even 90/10 income differential (see Subsection 3.2).

\footnotetext{
${ }^{8}$ The PSID is far less comprehensive than the CEX. Blundell et al. (2008) find that trends in the variance of consumption are very similar in the two datasets. Fisher and Johnson (2006, p. 16, table 3) compute a Gini coefficient for total consumption using both the CEX and imputed data for the PSID. Their numbers show a smaller increase in consumption inequality for the PSID data (1.2 per cent) than for the CEX data (4.7 per cent) for 1984-1999.
} 
Equally important, and related to the above, the distinction between between-group and within-group inequality in Krueger and Perri $(2003,2006)$ is conceptually problematic if inequality is also driven by other factors apart from education, race and sex. Although Krueger and Perri (2003, p. 15) argue that these are the "most important determinants of the changes of between-group earnings inequality in the last 30 years”, the issue is clearly more complicated. The most frequently discussed candidate explanations of the rise in U.S. inequality include: skill-biased technological change (e.g. Autor et al., 1998; Acemoglu, 1999; Goldin and Katz, 2008); globalisation including increasing trade, immigration, and off-shoring (Roberts, 2010); the emergence of superstars and winner-take-all markets (e.g. Rosen, 1981; Frank and Cook, 1995); rent-seeking behaviour by top executives especially in the financial sector (e.g. Murphy et al., 1991; Piketty and Saez, 2006; Philippon and Resheff, 2009); deficiencies in the educational system (e.g. Goldin and Katz, 2008); changes in labour market institutions including the erosion of the real minimum wage and the decline of the trade unions (Lee, 1999; Card et al., 2004; Gosling and Lemieux, 2004; Levy and Temin, 2007; Lemieux et al., 2009; Dube et al., 2011); changes in the tax system (e.g. Brownlee, 2004; Piketty and Saez, 2007); and social norms including, for instance, the political orientation of the government (e.g. Bartels, 2008; Hacker and Pierson, 2010). In other words, Krueger and Perri (2003, 2006) may underestimate the degree of between-group inequality.

This concern is corroborated by findings from statistical studies on income mobility. Gottschalk and Moffitt (1994), using PSID data, while emphasising their finding of rising earnings instability find that the permanent and transitory earnings component contributed roughly proportionally to the increase in earnings variance among white men from 1979 to 1987. Moffitt and Gottschalk (2002, 2008) extend this analysis to 2004. They confirm that the variance of both permanent and transitory earnings has risen in the 1980s, but the variance of transitory earnings is found to have declined or remained constant thereafter. Sabelhaus and Song (2009), applying similar statistical methods to different data sets, also find that the variance of transitory shocks unlike that of permanent shocks, has declined from the mid-1980s to the mid-1990s and since remained flat. These results seem to conflict with the view that the rise in inequality was driven by insurable temporary income shocks over the 1990s. Bradbury and Katz (2002a, 2002b), also using the PSID, analyse family income mobility by examining the percentage of families that move from one quintile to another from the first to the last year of a given time period. They find that mobility patterns were very similar in the 1970s and 1980s, but that mobility declined noticeably in the 1990s. They conclude that "while some hoped that increased mobility had offset the increased inequality in the 1980s and 1990s, the- 
se data provide no evidence of such an offsetting role” (Bradbury and Katz, 2002b, p. 5). ${ }^{9}$ The finding of little change in family income mobility between the 1970s and 1980s also confirms the results obtained by Gittleman and Joyce (1999). Auten and Gee (2009) emphasise that there was considerable income mobility in the U.S. in the periods 1987-1996 and 1996-2005, but their analysis does not suggest that higher inequality has been offset by higher mobility in the later period. For example, around 69 per cent of those taxpayers who were in the top income quintile in 1996 were still in the top quintile in 2005. The corresponding number for the period 1987-1996 was 62 per cent. Of the top 1 per cent of all tax taxpayers in 1996, around 41 per cent were still in the top 1 per cent in 2005. Roughly the same degree of mobility was observed for the period 1987-1996. Kopczuk et al. (2010), using Social Security Administration (SSA) earnings data, compare Gini coefficients based on annual earnings and 5-year to 20-year average earnings and conclude that "increases in annual earnings inequality are driven almost entirely by increases in permanent earnings inequality, with much more modest changes in the variability of transitory earnings” (p. 125). Only very long-term income mobility has somewhat increased (though not after the late 1970s), but this is entirely due to the increased labour force participation and higher wages of women. Kopczuk et al. (2010) also compute the top 1 per cent earnings share based on both annual and five-year average earnings and find that the two series have increased sharply in lock step since 1980. These conclusions are also consistent with available cross-country evidence. OECD (2008, p. 158) finds a statistically significant positive relation between the simple poverty headcount (averaged over three years), on the one hand, and the rates of persistent and recurrent poverty, on the other.

In spite of these concerns, the results of Krueger and Perri (2003, 2006) were literally treated as accomplished facts by the press (NY Times, 11/07/2002; The Economist, 19/12/2007; Wall Street Journal, 12/15/2006; see also Gordon and Dew-Becker, 2008, p. 30, for a critique).

\subsection{The renaissance of the relative income hypothesis}

While the permanent income theory of consumption theory was, largely erroneously, invoked to explain the increased household demand for credit as a result of higher income mobility, it is unable to establish a link between rising inequality on the one hand and the fall in the aggregate saving rate together with rising household indebtedness on the other hand. If anything, higher income instability should increase saving to the extent that it leads to a higher uncer-

\footnotetext{
${ }^{9}$ Bradbury and Katz recognise, however, that the higher inequality in the 1990s has led to a larger dispersion of incomes within each quintile, which reduces the likelihood for any given family to move to another quintile.
} 
tainty about future earnings. Hence, the question arises as to whether other factors, affecting poor and rich households in the same way, may have caused the observed changes in consumption behaviour. Although the issue has been heavily researched immediately since the saving rate began to fall in the mid-1980s, no clear conclusions have ever been reached that could be easily interpreted within the standard theory (for extensive surveys, see Summers and Carroll, 1987; Bosworth, 1989; Bosworth et al., 1991; CBO, 1993; Gale and Sabelhaus, 1999; Parker, 1999; Guidolin and La Jeunesse, 2007). Guidolin and Jeunesse (2007, p. 512), after reviewing most of the aforementioned potential explanations, conclude: "The recent decline of the U.S. private saving rate remains a puzzle.” And Parker (1999, p. 363) remarks, somewhat disillusioned after his examination of other candidate explanations, that "prime candidates for explaining the consumption boom are factors that increase the effective discount rate of the representative agent” and that consumers have become more optimistic about future income growth. Yet, "[t]his explanation is untestable, and twenty years is a long consumption boom without yet seeing a shift to higher output growth.” (Parker, 1999, p. 363) Clearly, the Rajan hypothesis, by lifting the assumption of the representative agent, offers an alternative explanation of the decline in saving and concomitant rise in personal debt during the three decades before the Great Recession, linked to the rise in inequality.

Rajan (2010, p. 24) argues that the rising income spread between the $90^{\text {th }}$ and $10^{\text {th }}$ percentile, and especially between the $90^{\text {th }}$ and $50^{\text {th }}$ percentile of the income distribution, is primarily due to the rising “college premium”. ${ }^{10}$ He also argues that, as improvements in education have been falling behind the pace of technological change, the rising inequality of outcomes has been accompanied by a similar rise in the inequality of opportunity since the late 1970s (Rajan, 2010, pp. 29 et seq.; see also Goldin and Katz, 2008). In other words, the relatively high consumption path of lower and middle class households implies that these households have lived beyond their means (in terms of their permanent, not transitory incomes) for several decades.

The relative income hypothesis, initially formulated by Duesenberry (1949), provides an intuitive explanation for a number of stylised facts that competing theories of consumption have failed to account for (Frank, 2005). Technically, the relative income hypothesis states that a household's saving rate will be independent of the absolute level of income but be an increasing function of (i) the household's position in the income distribution within its local

\footnotetext{
${ }^{10}$ Rajan (2010, pp. 28-9) recognises, however, that political factors such as the reduction of the marginal tax rate on high incomes, the weakness of trade unions, labour market deregulation and a relatively stagnant minimum wage may also have contributed to higher inequality.
} 
reference group and (ii) the relation of the household's current to past income. As such, it is related to other non-neoclassical theories of saving (see Brown, 2008).

Firstly, with respect to income distribution, it has some similarity with the Keynesian view of a positive, cross-sectional relationship between the level of income and the saving rate. ${ }^{11}$ However, Duesenberry rejects the simple Keynesian assumption that a rise in inequality is associated with a rise in aggregate saving because "[i]n these discussions it has been assumed that the effect of a redistribution can be judged by changing the weights applied to budget study data. That procedure is legitimate only on the assumption that individual consumption preferences are independent. If that is not so a decrease in inequality might increase the average propensity to save.” (Duesenberry, 1949, p. 44) Symmetrically, higher inequality may lead to a "keeping up with the Joneses" effect and a fall in the aggregate personal saving rate.

Secondly, by taking into account the impact of past and current income on current household saving, the relative income hypothesis bears some resemblance to the "disequilibrium hypothesis" or "habit persistence" theory (see Marglin, 1984, ch. 17, for a discussion). This may help explain why the personal saving rate has declined, not only in the U.S. but in most rich countries, since the 1980s, as income and consumption growth slowed after several decades of relatively high growth (Bosworth et al., 1991). However, it would appear difficult to attribute the 30 years of an almost continuously falling saving rate since the early 1980s to the persistence of habits acquired during previous decades. In effect, one problem with the hypothesis of a growth-saving nexus as outlined above is that it does not take into account the distribution of income between households. As a matter of fact, in the United States over the past 30 years, income growth for households at the top of the income distribution has actually been higher than in previous decades, but much lower for all others. In any event, the habit persistence effect and the keeping up with the Joneses effect can be expected to have affected aggregate personal saving in the same way, i.e., negatively, since the late 1970s.

The Rajan hypothesis at times appears to rely on the assumption of irrationality among lower income consumers:

"Stripped to its essentials, the argument is that if somehow the consumption of middle-class householders keeps up, if they can afford a new car every few years and the occasional exotic holiday, perhaps they will pay less attention to their stagnant monthly paychecks.” (Rajan, 2010, p. 8)

\footnotetext{
${ }^{11}$ Palley (2010, p. 42) argues that the relative income hypothesis provides a "micro-founded explanation of Cambridge-Kaleckian consumption and saving behavior”. Lavoie (1992, 2012) summarises the principles of Post Keynesian consumer theory, which contain all the ingredients of the relative income hypothesis.
} 
However, when the Rajan hypothesis is coupled with the relative income hypothesis, in its modern formulation, it becomes clear that from the point of view of households below the top of the income distribution credit-financed consumption may have been a completely rational reaction in the face of rapidly increasing consumption by top income households. Indeed, as noted by Frank et al. (2010, p. 8), "being influenced by community consumption standards [...] may be a perfectly rational response on the part of consumers in pursuit of widely recognized goals." More precisely, the model is based on what are "perhaps the two most robust findings from the behavioral literature on demonstration effects: 1) the comparisons that matter most are highly localized in time and space; and 2) people generally look to others above them on the income scale rather than to those below" (Frank et al., 2010, p. 7). Indeed, these basic features of human nature were well understood by early economists ranging from Adam Smith $^{12}$ to Thorstein Veblen ${ }^{13}$. The behavioural bottom line explanation is that a high status is the best way to achieve social recognition. Applied to consumption behaviour, this view gives rise to the distinction between positional and non-positional goods (Frank, 1985; Frank, 2005). Although the distinction is not clear-cut, positional goods are those goods where comparisons with others matter most, and non-positional goods are those where they matter least. For instance, saving for retirement, financial security (avoidance of high indebtedness) or leisure, tend to be perceived as non-positional goods. But the quality of education, cars, houses, clothes, jewellery etc. are positional goods. The problem, however, is that these and other forms of household expenditure are "driven by forces similar to those that govern military arms races” (Frank, 1997, p. 1840). In the extreme case, higher inequality, even if concentrated at the very top of the income distribution, can give rise to expenditure cascades all the way down the income ladder if individuals are indeed influenced by the spending patterns of others just above them in the income distribution (Frank et al., 2010). Yet, if everybody spends more on positional goods in reaction to higher inequality leading to higher relative expenditures by households' at the top, nobody (below the top) will see their status improve, but everybody will be more highly indebted and more financially insecure.

The extent to which expenditure cascades are triggered by rising inequality can be expected to depend crucially on the country-specific institutional environment. For one thing,

\footnotetext{
12 "A linen shirt, for example, is, strictly speaking, not a necessary of life. [...] But in the present times, through the greater part of Europe, a creditable day-labourer would be ashamed to appear in public without a linen shirt." (Adam Smith, 1776 [2009, p. 519])

13 "The motive is emulation - the stimulus of an invidious comparison [...]. [E]specially in any community in which class distinctions are quite vague, all canons and reputability and decency and all standards of consumption are traced back by insensible gradations to the usages and thoughts of the highest social and pecuniary class, the wealthy leisure class.” (Veblen, 1899 [2007, p. 71])
} 
the availability of household credit depends on the specific characteristics of the credit system. Moreover, when schooling and higher education are largely financed privately or the quality of public schools is related to the material standard of living in the respective school districts, there may be strong incentives for families to reduce savings and increase debt in order to attain the best possible education for their children. More generally, in a country with strongly rising inequality, very large top income shares, and a low degree of intergenerational income mobility, the returns to education (and other forms of expenditure signalling potential for higher status) will appear especially high (OECD, 2008, ch. 8). In the United States, intergenerational mobility is already low by international standards and further declining (see OECD, 2008, ch. 8; Bowles and Gintis, 2002; Mazumder, 2005; Andrews and Leigh, 2009). As noted by Rajan (2010, p. 28-29): "Because the well-connected and the highly educated tend to mate more often with each other, 'assortative' mating has also helped increase household income inequality.” Broader cultural trends likely play an important role as well (e.g. Cynamon and Fazzari, 2008)

Finally, even though the relative income model does not imply irrational behaviour on the part of consumers, it may additionally be the case, as argued by Stiglitz (2008), that preferences evolve endogenously in response to a variety of forces including inequality, again depending on country-specific institutions and culture. It can be argued, for instance, that "in a world in which people are especially attuned to differences in income [...] the return to targeted advertising can be especially high. If one induces 'consumer leaders' to buy SUVs, other consumers will follow.” (Stiglitz, 2008, p. 57)

In the next section, we will review some empirical evidence supporting the consumption theory underlying the (augmented) Rajan hypothesis as outlined above.

\section{How did consumers react to higher inequality?}

\subsection{From near saturation to a new perception of need?}

Figure 6 compares the growth rate of median income for families of four with the growth rate of what consumers perceive as the minimum amount of yearly income a family of four would need to "get along in your local community". In the figure, we present survey data from a Gallup poll for yearly mean estimates of minimum income for the period 1957-1992 (Vaughan, 2004) and median estimates for the years 1947, 1967, 1987, and 2007 (Jones, 2007). Two things are noteworthy here: The first is the very different relationship between the growth rates of the two measures for the three periods for which data are available (Figure 
6a). From 1947 to 1967, both the perceived minimum income and actual median income grew considerably, and the actual income growth was even somewhat higher than the growth of subjective minimum income for the median family. Interestingly, in 1987 the amount of money that was perceived as necessary to "get along” was no higher than in 1967, while median family income continued to grow quite considerably (and roughly in line with mean family income) during 1967-1987. In other words, it would seem that the typical American family of four considered their material standard of living as (more than) satisfactory during that period, despite a slowdown in growth (which is evidence against the pure habit persistence hypothesis). And yet, after 1987 the amount of income considered necessary to get along again increased strongly, by more than 40 per cent until 2007, even though median real incomes were more than 15 per cent higher in 2007 than in 1987. Notice that subjective minimum income even increased by more than actual mean income during this most recent period. As can be seen in Figure 6b, these trends lead to a U-shaped ratio of subjective minimum income to actual income, with a turning point some time in the early 1980s. ${ }^{14}$ Also notice that the shape of these graphs is not dissimilar to those of top income shares in Figure 3 above. Taken together, these data provide evidence for the relative income hypothesis, which holds that most individuals will (rationally) develop consumption norms by looking at the consumption of others above them.

The second important observation from Figure 6 is that during the period 1987-2007 median family incomes developed considerably better (+ 16.9 per cent) than either median male ( -1.5 per cent) or even female $(+13.9$ per cent) hourly real wages, and also more than median individual male ( +6.9 per cent) or household $(+10.4$ per cent) income over the period 1987-2007 (median individual female income increased by 44.5 per cent, all figures from the CPS). It is thus important to consider changes in labour supply, which are also likely linked to changes in inequality.

\subsection{Labour supply, saving and debt: three coping mechanisms}

There are various mechanisms through which households can attempt to prevent a decline in (relative) consumption in the face of an adverse development in individual hourly wages. First, individual working hours can be increased; second, family labour supply can be raised, i.e., an additional household member can enter the paid labour force; third, taxes and transfers, although beyond the control of the individual household, provide an additional

\footnotetext{
${ }^{14}$ Note that in the mid-1960s the Gallup mean estimate of minimum income increases relative to the official poverty line but decreases relative to median income.
} 
mechanism by which the effect of lower wages on consumption is alleviated; and finally, households can reduce saving and increase debt as a means of financing consumption. Reich (2010, ch. I.8) provides casual evidence for these various "coping mechanisms" at the disposal of households below the top of the income distribution who were reluctant to accept a permanent decline in relative consumption in spite of a permanent decline in relative wages, as hypothesised by Rajan (2010).

A first indication of the importance of these coping mechanisms is given in Figure 7, which shows that virtually all of the increase in median family income since the 1970s can be attributed to married couples where the wife is in the labour force. This is explained, first, by the relatively positive development of median female wages and, second, by the strong increase in women's participation in the labour force. In fact, whereas the higher female participation rates were matched almost one-by-one by lower male participation rates before the late 1970s, total participation increased rather strongly starting in the late 1970s and throughout the 1980s, i.e., precisely when income inequality started to rise. Since the early 1990s, the overall participation rate remains at a roughly constant level of just less than 70 per cent. Moreover, although men's overall participation in the labour force has continued to decline somewhat after the late 1970s, annual hours worked of those remaining in the labour force did not decrease, and even increased slightly between 1979 and 2000. At the same time, women strongly increased the number of hours worked, in addition to higher participation in the labour force. Interestingly, the number of hours worked increased most in the second and third income quintiles. It increased also in the highest and lowest quintile, but to a lesser degree. Taken together, these developments imply a higher average family labour supply and have contributed to a large extent to the overall increase in hours worked per capita in the U.S. over the past decades. As highlighted by Blanchard (2004), both the strong increase in the participation rate and the only very small decrease in hours worked per worker in the U.S. are rather exceptional by international standards. In the European Union (EU-15) and especially in France, for instance, where income inequality has not increased as much (it has actually declined in France), the hours worked by the population of working age have rather strongly decreased in 1970-2007.

Two other developments more relevant for financial instability were the dramatic drop in personal saving and the surge in personal debt that also started precisely at the time when inequality began to rise (Figure 8 and Figure 9). It is perhaps worth noting that both the saving rate and the aggregate personal debt-to-income ratio correlate more strongly with top (10 or even 5 per cent) income shares than with the Gini (Figure 9). This is also consistent 
with the findings in Figure 10, based on the Survey of Consumer Finances (SCF), which shows that all households except the top 10 per cent have become more strongly indebted since the late 1980s (see also Kumhof and Rancière, 2010, figure 5). In 1989, the debt-toincome ratio was around 60 per cent for the top 10 per cent of household incomes and around 80 per cent for all other groups. In 2007, the respective ratios were around 80 per cent for the top 10 per cent, 250 per cent for the bottom quintile, and between 150 and 180 per cent for those groups in the middle. Wolff (2010) reports that the debt-to-equity and debt-to-income ratios have declined from 1983 to 2007 for the top 1 per cent of the wealth distribution, but increased for the next 19 per cent and the middle quintiles.

\subsection{Evidence for the effects of rising inequality on household be- haviour}

Beyond the descriptive statistics, more formal empirical evidence also supports the view that labour supply, saving and financial decisions were indeed strongly influenced by changes in income distribution in the United States during the decades prior to the crisis. It seems reasonable for our purpose to consider these coping mechanisms together because it is probable that households respond to rising inequality in a variety of ways, and the excessive use of credit may imply that other, seemingly less problematic coping mechanisms have become overstretched.

Considering first the link between inequality and labour supply, Bowles and Park (2005), after estimating a panel data model for 10 European and Northern American countries for the period 1963-1998, conclude that greater inequality is indeed associated with longer work hours, controlling for other factors typically included in labour supply models, such as the real wage, real GDP per capita, union density, the unemployment rate, and the female proportion in employment. According to their estimates, a standard deviation change in inequality raises annual hours worked by 1.8 to 3.4 per cent, depending on the measure of inequality. Interestingly, the effect is larger for the 90/50 income differential than for either the Gini or the Theil index, a finding that is consistent with the expenditure cascades hypothesis discussed in the previous section. They interpret their findings as evidence of "Veblen effects", taking into account that in Veblen's work the reference group is the rich. ${ }^{15}$

\footnotetext{
${ }^{15}$ As argued by Stiglitz (2008, p. 549): “Those who, because of lower productivity, inevitably consume less, still strive to reduce the observed gap between their consumption and that of their richer neighbors. It is the rich that define the aspirations of the rest of society. At the same time, those at the top struggle to separate themselves from those below. It is only by working hard and conspicuously consuming the fruits of that work that they can demonstrate their superiority. There is, in effect, an arms race, a race to consume more and more, working harder and harder, in which no one is the winner.”
} 
These results are confirmed by findings in Bell and Freeman (2001) who use the National Longitudinal Survey of Youth (NLSY) and estimate the effect of the dispersion of hourly wages on hours worked. It is argued that workers choose current hours of work to gain promotions and advance in the distribution of earnings. Bell and Freeman (2001) also compare labour supply decisions in the United States and Germany and contribute the longer working hours in the United States to the more unequal earnings distribution. Freeman (2007, p. 63) also points to the fact that more Americans than Europeans say that they want to increase rather than decrease hours worked at given wage rates and that they work hard even if it interferes with the rest of their life. This phenomenon may indeed be linked to higher inequality in the U.S., leading to a "tournament style economic system that gives the person who puts in an extra hour of work a potentially high return” (Freeman, 2008a, p. 137).

Neumark and Postlewaite (1998), also using data from the NLSY, find that women whose sister's husband had a higher income than their own husband were between 16 and 25 per cent more likely to participate in the paid labour force. The comparison of labour supply decisions of relatives is interesting because it can be expected that relatives are typically members of a person's social reference group.

Importantly, working time statistics do not capture those hours that are not spent at the workplace but are clearly work-related and certainly cannot be considered as leisure, i.e., in particular, commuting time. Frank (2007) quotes evidence that traffic delays for rush-hour commuters in major U.S. cities roughly tripled between 1983 and 2003. There is also evidence that individuals in the United States sleep considerably less today than in past decades - by some estimates as much as one to two hours per night less than in the 1960s (McCoy, 2004). Similarly, Americans spend less time with families and friends today than in the past (Putnam, 2000; Neumark-Sztainer et al., 2003).

There may also be self-reinforcing processes at work as far as the relationship between hours worked and consumption is concerned. Stiglitz (2008) argues that on the one hand, consumers work more to "keep up with the Joneses", but on the other hand, the fact that higher working hours for all make it more difficult to coordinate one's leisure time with friends and family may further increase the relative demand for goods at the expense of leisure time. The reason is that leisure time becomes less valuable when it has to be spent alone rather than with members of one's family or community. As a consequence, consumers may see consumption as a palliative not only against mediocre monthly paychecks, as argued by Rajan, but also against the fact that they spend less time with their families and friends. Moreover, in a society where individuals work a lot and spend less leisure time in community with friends and 
family, specific types of "culture” which require learning, repetition, trust, etc. (rather than the purchase of marketable goods) are less likely to develop. For instance, as emphasised by Stiglitz (2008), the "slow food movement" is more popular in Europe than in the United States.

Some studies have tested the relative income hypothesis of saving econometrically. Focusing on household saving of a sample of U.S. workers, Schor (1998) asked workers how their "financial status" compared to that of those in their reference group (as defined by respondents themselves, consisting primarily of co-workers, friends, relatives and persons of the same religion). She found that, after controlling for a measure of permanent income as well as a set of other variables such as sex, age, race or occupation and education, the financial status compared to the self-defined reference group had a significantly positive impact on household saving. This effect was substantial, as each step up in financial status (on a scale from 1 to 4 ) raised annual saving by almost $\$ 3,000$.

Bertrand and Morse (2011) use CEX data to estimate the effects of the expenditures of rich households (above the $80^{\text {th }}$ income percentile) on those of non-rich households. They find clear evidence of "top-down consumption spillover effects" and argue that their results are "most consistent with the view that visible increased consumption by the rich induces statusseeking or status-maintaining consumption by the less rich.” (Bertrand and Morse, 2011, p. 1) Interestingly, higher expenditures by the rich have a larger effect on the middle class than on the lower and poverty classes. This is evidence in support of the expenditure cascades hypothesis.

Frank et al. (2010) provide indirect evidence for the expenditure cascades hypothesis. To begin with, they point to the fact that the median size of a newly constructed houses in the U.S. has increased more than twice as rapidly as the increase in the median family earnings from 1980 to 2001 (from approximately 1,600 to more than 2,100 square feet), although at the same time one in five households had zero or negative net worth. ${ }^{16}$ Using data for the 50 U.S. States and 100 most populous counties ${ }^{17}$ from the 1990 and 2000 installments of the U.S. Census, they estimate a series of regressions and find that income inequality, after controlling for standard explanatory variables, is positively related to various measures of financial

\footnotetext{
${ }^{16}$ Gordon (2008, p. 39) finds that American households occupy roughly double the internal square feet of area and roughly four times the external square feet of area as Europeans. Gordon and Dew-Becker (2008, p. 31) argue, therefore, that the consumption of housing quantity and quality by Americans might be more equal than income, but add that the benefits of large exurban houses may be partly mitigated by longer commuting times.

${ }^{17}$ The decision to focus on the most populous counties is consistent with Thorstein Veblen's observation that "consumption claims a relatively larger portion of the income of the urban than of the rural population... [because] the insistence on [consumption] as an element of decency is at its best [...] where the human contact of the individual is widest and the mobility of the population is greatest.” (Veblen, 1899 [2007, p. 61])
} 
distress. Frank et al. (2010) also quote evidence suggesting that median house prices were substantially higher in school districts with higher levels of income inequality, as measured by the 95/50 ratio, even after controlling for median income.

In Figure 11, we apply a simple variant of the expenditure cascades model developed by Frank et al. (2010) to two different data sets for U.S. household income by quintile. Interestingly, despite the crudeness of the model, the simulated saving rates match the NIPA series rather well, until the Great Recession, for plausible parameter values.

The main point of the Rajan hypothesis is that consumers have used credit to compensate for the lack of income growth. In earlier contributions, Pollin $(1988,1990)$ made essentially the same point, concluding from his extensive analysis of the Survey of Consumer Finances for 1970, 1977, 1983, and 1986, that “[f]or those [households] in the lower 80 per cent of the income distribution, borrowing is largely a result of the need to maintain living standards in the face of the stagnation in real incomes since the early 1970s and the corresponding rise in real living costs, especially for housing" and that "household indebtedness [...] is the financial mirror of the widely-noted trend in the real economy over this period toward greater inequality.” (Pollin, 1988, p. 1) Similar descriptive evidence for more recent years was provided by Barba and Pivetti (2009).

There is also some econometric evidence suggesting that the rise in income inequality and household debt in the United States are directly related. Pollin (1988) uses aggregate time series for the period 1953-1985 to investigate the demand-side influences on the rise in personal debt since the mid-1970s. Regression results provide tentative evidence that increased necessitous demand in the face of declining real median incomes have been an important cause for the trend rise in household credit since the mid-1970s. Christen and Morgan (2005) use aggregate times data for the period 1980-2003 and find a strong positive effect of income inequality on household debt relative to disposable income, while controlling for a set of other variables. They also find that ignoring income inequality leads to a much lower estimate of the "wealth effect". They conclude that "[m]ost important for marketers, the income inequality effect is strongest for non-revolving debt, which is used to finance consumer durable purchases” (Christen and Morgan, 2005, p. 148). Boushey and Weller (2006), also using aggregate time series for the period 1980-2003, estimate the effects of various measures of inequality on different types of household debt and find some evidence that higher inequality is related to higher debt, while controlling for other determinants of debt. 
Iacoviello (2008) constructs a model in which credit serves as a substitute for income growth in the financing of consumption. In particular, the model simulation matches the observed trend rise in personal debt since the 1980s which in the model "reflects the increased access of households to the credit market in order to smooth consumption in the face of more volatile incomes.” (Iacoviello, 2008, p. 931) Although this wording makes the interpretation sound rather akin to that described by Krueger and Perri (2006), Iacoviello's model produces not only a small increase in consumption inequality, compared to income inequality, and a strong rise in personal debt, but also a strong increase in wealth inequality relative to income inequality, a result that conforms with the empirical facts but contradicts the permanent income model and the Krueger and Perry analysis of merely higher transitory income variability. Consequently, Iacoviello (2008, p. 957) emphasises that in his paper "the mechanism through which consumption inequality rises less than income inequality is an expansion of credit from the rich to the poor.”18 The similarities with the Rajan hypothesis are obvious.

\subsection{Demand or supply, immoral debtors, predatory lenders, or coward politicians?}

In the previous Subsection we discussed the effects of rising inequality in terms of the behaviour by households below the top. Yet, there is a heated political debate about whether "the poor caused the crisis” by borrowing excessively (see Johnson, 2011), and whether the main causes of excess credit are to be found in the corporate governance and risk management of financial institutions or in government policies aiming at promoting credit to middle class voters (see FCIC, 2011). In the academic literature, there is a related debate as to whether the expansion of personal credit was driven by demand or by supply and, therefore, about the precise channels through which income inequality has affected aggregate demand.

As discussed above, Kruger and Perri (2006) interpret the rise in personal debt as a demand-side phenomenon, linked to higher transitory income dispersion and an endogenous development of credit markets. While this interpretation is largely contradicted by the empirical evidence, others have pointed to the more direct negative aggregate demand effects of rising permanent inequality, due to a lower propensity to consume of high income households, and the offsetting effect of a higher credit demand of households below the top (e.g. Palley, 2002, 2012; Dutt, 2006; Barba and Pivetti, 2009). By contrast, Rajan (2010) highlights devel-

\footnotetext{
${ }^{18}$ In the working paper version, Iacoviello (2005, p. 23) stressed that "the model here is not able to generate steady states in which consumption inequality is lower than income inequality, as in Krueger and Perri (2005): rather, the purpose of my exercise is to show how the smaller increase in consumption inequality that we have seen in the period under exam can be rationalized through a larger access to the credit market.”
} 
opments on the supply side (together with higher permament income dispersion). Similarly, Kumhof and Rancière (2010) emphasise the notion that agents derive direct utility from the social status conferred by wealth, so that the higher leverage of non-rich consumers results from the higher credit supply resulting from increased saving of the rich as a result of higher inequality. A related debate is about the extent to which changes on the supply side were driven by political support for household credit, as emphasised by Rajan (2010), and the extent to which they were market-driven. Fitoussi and Stiglitz (2009) argue that monetary policy was endogenous to the structural disequilibrium in income distribution in the sense that without a continuously expansionary monetary policy aggregate demand deficiency would have affected economic activity. Another popular debate is whether it is primarily lenders that must be blamed for predatory lending practices, or whether immoral debtors have lied about their creditworthiness and borrowed irresponsibly beyond their means. As part of this debate, some authors have harshly criticised the view that American households “overspent” (Schor, 1998) and were infected by a sort of "luxury fever" (Frank, 1999). Warren and Warren Tyagi (2004), for instance, have called this the "over-consumption myth", and denounce the view that frivolous consumption was financed by debt as the "immoral debtor myth". ${ }^{19}$

In our view, there are no clear answers to these questions as demand-side and supply-side influences on consumer borrowing are difficult to disentangle. To begin with, it should be noted that there are serious empirical doubts as to whether households' demand for credit is even remotely in line with the rational expectations assumption of standard consumption models, as implied by the Greenspan-Krueger-Perri argument. For instance, as a Gallup poll (Moore, 2003) showed, 31 per cent of the total population and 51 per cent of adults below the age of 29 expected to become "rich" (Table 1). However, only 2 per cent of the overall population considered themselves to be "already rich". For the age groups 50-64 and 65+, the percentage of households considering that they are "already rich“ were 4 and 2 per cent, respectively. Yet, the percentage of households who found it "very/somewhat likely to be rich" was still as high as 22 and 8 per cent, respectively. The median subjective estimate of what it requires to be rich was $\$ 1,000,000$ in assets, or $\$ 122,000$ in annual income. This was, of course, much higher than, respectively, actual median and mean net worth and actual median and

\footnotetext{
${ }^{19}$ Warren and Warren Tyagi (2004, p. 16) argue that "[t]he Over-Consumption Myth rests on the premise that families spend their money on things they don't really need." They then use data from the CEX to examine whether "today's families are spending more on [...] frivolous items than ever before" (p. 16). They conclude that real per capita consumption has hardly increased for most items and most households. Given the limitations of the CEX consumption data discussed above, this conclusion is to be judged with great caution. But more fundamentally the critique by Warren and Warren Tyagi (2004) seems to miss the main point of the "overspending" or "luxury fever" hypotheses, which is that the individual perception of material needs is highly sensitive to context.
} 
mean household income in 2003. Interestingly, the optimism of U.S. households does not seem to have been negatively affected by actual trends in median income growth over the years. As Table 2 shows, the perceived likelihood of getting rich has remained roughly constant from 1990 to 2003.

While, in light of these numbers, the very harsh critique by some authors of the "luxury fever" hypothesis appears exaggerated, they do not in any sense validate the "immoral debtor myth” (Warren and Warren Tyagi, 2004). Rather, these results are consistent with the wellknown "better-than-average effect" from the psychology and behavioural economics literature (Alicke and Govorun, 2005). There is, moreover, ample empirical evidence suggesting that consumers lack the cognitive capability to solve the intertemporal optimisation problem required by the life-cycle hypothesis. Clearly, when a very large fraction of households believe that they will be millionaires in the future, taking on large amounts of debt may seem justified from an individual perspective. In fact, it seems quite likely that income expectations are at least in part driven by the supply of credit. For instance, Soman and Cheema (2002, p. 32) find that consumers use information such as the credit limit as a signal of their future earnings potential: "Specifically, if consumers have access to large amounts of credit, they are likely to infer that their lifetime income will be high and hence their willingness to use credit (and their spending) will also be high.” This is also consistent with the conclusion of an extensive survey by Senik (2005) that perceived (rather than actual) mobility explains the link between other people's income and individual satisfaction, as it determines individual opportunities and risks and, therefore, consumption and saving behaviour. It therefore seems to us that Rajan's (2010) categorical endorsement of a supply-side explanation of credit expansion is somewhat exaggerated, given the apparent interaction of the supply and demand for credit.

Similarly, Rajan's strong emphasis on the role of government in promoting credit also seems somewhat unbalanced. Hyman (2011), in his detailed history of borrowing in the United States, argues that consumers simply continued to borrow since the 1980s as they had done in earlier decades, in spite of lower income growth, and the credit system largely accommodated this (see Hyman, 2011, p. 4). Note that this explanation is almost the exact opposite of the conclusion by Krueger and Perri (2006, p. 187) that consumers started to make stronger use of credit markets "exactly when they needed to". Rather, it would seem that consumers did not stop making strong use of credit markets when they needed to, i.e., they continued to consume heavily despite smaller income gains. In another dimension, however, Hyman's analysis differs from the Rajan hypothesis and is closer to Krueger and Perri $(2003,2006)$ in that it emphasises the endogenous response of credit markets to rising inequality which was in 
large part independent of government intervention. A very similar case is made by Brown (2008, ch. 3) who argues that private lenders themselves developed strategies to cope with the slower income growth and reduced financial solidity of their clients. Examples of these strategies are the extension of loan maturities, captive finance, and securitisation.

Another debate is whether it can really be said, as in the Rajan hypothesis, that by promoting credit politicians have responded to the demands of lower and middle-income voters (see Acemoglu, 2011, for a critique). Rajan (2010, p. 39) argues that this is at least indirectly the

case: "Even if no politicians dreamed up a Machiavellian plan to assuage anxious voters with easy loans, their actions - and there is plenty of evidence that politicians pushed for easier housing credit - could have been guided by the voters they cared about” (Rajan, 2010, p. 39). Yet, it has been noted that the U.S. political system is mainly responsive to high-income voters (e.g. Gilens, 2005; Bartels, 2008). One explanation for this may be lobbying and the dependence of political parties on fund-raising (e.g. Hacker and Pierson, 2010). A direct response to this critique would be that high-income voters can be expected to prefer credit promotion to the social instability that may result from high (consumption) inequality but also to outright “soak the rich” policies. Rajan (2010, p. 31), in fact, makes precisely this point: “Government-supported credit does not arouse as many concerns from the Right at the outset as outright income redistribution would.” Bratt (2008) provides ample evidence that the concept of "homeownership as social policy" has indeed a long tradition in the United States and that it has become increasingly market-oriented since the Reagan government.

In sum, these debates while interesting do not seem to call into question the fundamental macroeconomic implication of the Rajan hypothesis. The bottom line is that the "market presented consumers with sub-optimal choices that they took” (Green, 2008, pp. 262-263) and that this expansion of personal debt helped to temporarily solve the aggregate demand problem caused by rising inequality.

\section{Summary and conclusions}

There is substantial evidence that the rising inter-household inequality in the United States has importantly contributed to the fall in the personal saving rate and the rise in personal debt (and a higher labour supply). Aided by the easy availability of credit, lower and middle income households attempted to keep up with the higher consumption levels of top income households. This has contributed to the emergence of a credit bubble which eventually burst and triggered the Great Recession. In other words, there is strong support for the Rajan hy- 
pothesis beyond the anecdotal evidence presented by Rajan (2010) and the evidence from cross-country panel regressions. In addition, the Rajan hypothesis, while inconsistent with the permanent income hypothesis, calls for a renaissance of the relative income hypothesis. 


\section{References}

Acemoglu, D. (1999), Changes in unemployment and wage inequality: An alternative theory and some evidence, American Economic Review 89(5), 1259-1278.

Acemoglu, D. (2011), Thoughts on Inequality and the Financial Crisis, presentation held at the American Economic Association, http://economics.mit.edu/files/6348

Alicke, M. D. \& Govorun, O. (2005), The better-than-average effect, in M.D. Alicke; D.A. Dunning \& J.I. Krueger, ed., The Self in Social Judgment, Psychology Press, 85-106.

Ando, A. \& Modigliani, F. (1963), The life cycle hypothesis of saving: Aggregate implications and tests, American Economic Review 53(1), 55-84.

Andrews, D. \& Leigh, A. (2009), More inequality, less social mobility, Applied Economics Letters 16, 1489-1492.

Atkinson, A. \& Morelli, S. (2010), Inequality and Banking Crises: A First Look, Paper prepared for the European Labour Forum in Turin organised by the International Training centre of the International Labour Organization (ILO).

Attanasio, O.; Battistin, E. \& Ichimura, H. (2007), What really happened to consumption inequality in the United States?, in Ernst R. Berndt \& Charles R. Hulten, ed., Hard-tomeasure Goods and Services: Essays in Honor of Zvi Griliches, University of Chicago Press, .

Auten, G. \& Gee, G. (2009), Income mobility in the United States: New evidence from income tax data, National Tax Journal 67(2), 301-328.

Autor, D. H.; Katz, L. F. \& Krueger, A. B. (1998), Computing inequality: Have computers changed the labor market?, The Quarterly Journal of Economics 113(4), 1169-1213.

Barba, A. \& Pivetti, M. (2009), Rising household debt: Its causes and macroeconomic implications - A long-period analysis, Cambridge Journal of Economics 33, 113-137.

Battistin, E. (2003), Errors in Survey Reports of Consumption Expenditures, IFS Working Papers (W03/07), Institute for Fiscal Studies.

Bell, D. N. \& Blanchflower, D. G. (2009), What Should Be Done About Rising Unemployment in the OECD?, IZA Discussion Papers (4455), Institute for the Study of Labor (IZA).

Bell, L. A. \& Freeman, R. B. (2001), The incentive for working hard: Explaining hours worked differences in the US and Germany, Labour Economics 8(2), 181-202.

Bertrand, M. \& Morse, A. (2011): Consumption contagion: Does the consumption of the rich drive the consumption of the less rich?, http://faculty.chicagobooth.edu/adair.morse/research/NBER_reporter_summaryAug201 1.pdf

Blundell, R. (2011), From income to consumption: Understanding the transmission of inequality, Focus 28(1), 23-30.

Blundell, R.; Pistaferri, L. \& Preston, I. (2008), Consumption inequality and partial insurance, American Economic Review 98(5), 1887-1921.

Bofinger, P. (2012), The Impact of Inequality on Macroeconomic Dynamics, Paper presented at the Conference "Paradigm Lost”, Institute for New Economic Thinking, 12-14 April 2012

Bordo, M.D. \& Meissner, C.M. (forthcoming), Does inequality lead to a financial crisis?, Journal of International Money and Finance.

Bosworth, B. P. (1989), There's no simple explanation for the collapse in saving, Challenge July-August, 27-32.

Bosworth, B.; Burtless, G. \& Sabelhaus, J. (1991), The decline in saving: Evidence from household surveys, Brookings Papers on Economic Activity 1, 183-256.

Boushey, H. \& Weller, C. E. (2006), Inequality and Household Economic Hardship in the 
United States of America, Working Papers (18), United Nations, Department of Economics and Social Affairs.

Bowles, S. \& Gintis, H. (2002), The inheritance of inequality, Journal of Economic Perspectives 16(3), 3-30.

Bowles, S. \& Park, Y. (2005), Emulation, inequality and work hours: Was Thorsten Veblen right?, The Economic Journal 115, F397-F412.

Bradbury, K. \& Katz, J. (2002a), Issues in economics: Are lifetime incomes growing more unequal? Looking at new evidence on family income mobility, Regional Review (Q 4), 2-5.

Bradbury, K. L. \& Katz, J. (2002b), Womens labor market involvement and family income mobility when marriages end, New England Economic Review (Q 4), 41-74.

Bratt, R. G. (2008), Homeownership as Social Policy in the U.S.: Risk and Responsibility after the Subprime Crisis, Paper presented at the ENHR Working Group Building on Home Ownership: Housing Policies and Social Strategies, November 13th and 14th 2008, Delft University of Technology, the Netherlands.

Brown, C. (2008), Inequality, Consumer Credit and the Saving Puzzle, Edward Elgar.

Brownlee, W. E. (2004), Federal Taxation in America: A Short History. 2nd Edition, Cambridge University Press.

Card, D.; Lemieux, T. \& Riddell, W. C. (2004), Unions and wage inequality, Journal of Labor Research 25(4), 519-562.

Carlin, W. \& Soskice, D. (2007), Reforms, Macroeconomic Policy and Economic Performance in Germany, CEPR Discussion Paper No. 6415. Also published as Carlin, W. \& Soskice, D. (2008), Reforms, macroeconomic policy and economic performance in Germany, in R. Schettkat \& J. Langkau, ed., Economic Policy Proposals for Germany and Europe, Routledge, 72-118.

CBO (Congressional Budget Office) (1993), Assessing the Decline in the National Saving Rate, Congressional Budget Office.

CBO (2010), Trends in Federal Tax Revenues and Rates, http://www.cbo.gov/publications/collections/tax/2010/all_tables.xls.

Christen, M. \& Morgan, R. M. (2005), Keeping up with the Joneses: Analyzing the effect of income enequality on consumer borrowing, Quantitative Marketing and Economics 3(2), 145-173.

Cynamon, B. \& Fazzari, S. (2008), Household debt in the consumer age - source of growth and risk of collapse, Capitalism and Society 3, 1-30, 2008.

Dube, A.; Lester, T. W. \& Reich, M. (2011), Do Frictions Matter in the Labor Market? Accessions, Separations, and Minimum Wage Effects, Institute for Research on Labor and Employment, Working Paper Series (1622839), Institute of Industrial Relations, UC Berkeley.

Duesenberry, J. S. (1962 (1949)), Income, Saving and the Theory of Consumer Behavior, Harvard University Press.

Dutt, A.K. (2006), Maturity, stagnation and consumer debt: a Steindlian approach, Metroeconomica, 57, 339-364.

Eccles, M. S. (1951), Beckoning Frontiers: Public and Personal Recollections, Alfred A. Knopf.

FCIC (Financial Crisis Inquiry Commission) (2011), The Financial Crisis Inquiry Report: Final Report of the National Commission on the Causes of the Financial and Economic Crisis in the United States, The Financial Crisis Inquiry Commission, http://fcicstatic.law.stanford.edu/cdn_media/fcic-reports/fcic_final_report_full.pdf

Fisher, J. D. \& Johnson, D. S. (2006), Consumption mobility in the United States: Evidence from two panel data sets, The B.E. Journal of Economic Analysis \& Policy 6(1), Article 16. 
Fitoussi, J.-P. \& Stiglitz, J. E. (2009), The Ways Out of the Crisis and the Building of a More Cohesive World, Document de Travail, OFCE (17), 471 - 482.

Frank, R. H. \& Cook, P. (1995), The Winner-take-all Society: How More and More Americans Compete for Ever Fewer and Bigger Prizes, Encouraging Economic Waste, Income Inequality, and an Impoverished Cultural Life, Free Press.

Frank, R. H. (1985), The demand for unobservable and other nonpositional goods, American Economic Review 75(1), 101-16.

Frank, R. H. (1997), The frame of reference as a public good, The Economic Journal 107, 1832-1847.

Frank, R. H. (1999), Luxury Fever: Why Money Fails to Satisfy in an Era of Excess, Free Press.

Frank, R. H. (2005), Positional externalities cause large and preventable welfare losses, American Economic Association Papers and Proceedings, 95(2), 137-141.

Frank, R. H. (2007), Falling Behind: How Rising Inequality Harms the Middle Class, University of California Press.

Frank, R. H.; Levine, A. S. \& Dijk, O. (2010), Expenditure cascades, http://ssrn.com/abstract=1690612.

Freeman, R. B. (2007), Labor Market Institutions Around the World, NBER Working Papers (13242), National Bureau of Economic Research, Inc.

Freeman, R. B. (2008a), Why do we work more than Keynes expected?, in L. Pecchi \& G. Piga, ed., Revisiting Keynes: Economic Possibilities for Our Grandchildren, MIT Press, 135-142.

Freeman, R. B. (2008b), Wanted: A new German Wirtschaftswunder, in R. Schettkat \& J. Langkau, ed., Economic Policy Proposals for Germany and Europe, Routledge, 144166.

Friedman, M. (1957), A Theory of the Consumption Function, Princeton University Press.

Galbraith, J. K. (1997 (1954)), The Great Crash of 1929, Mariner Books.

Galbraith, J. K. (2012), Inequality and Instability: A Study of the World Economy Just Before the Great Crisis, Oxford University Press.

Gale, W. G. \& Sabelhaus, J. (1999), Perspectives on the household saving rate, Brookings Papers on Economic Activity 1, 181-224.

Gilens, M. (2005), Inequality and democratic responsiveness, Public Opinion Quarterly 69, 778-796.

Gittleman, M. \& Joyce, M. (1999), Have family income mobility patterns changed?, Demography 36(3), 299-314.

Goldin, C. \& Katz, L. F. (2008), The Race Between Education and Technology, Harvard University Press, chapter: The evolution of U.S. educational wage differentials, 1890 to 2005.

Goldin, C. \& Margo, R. A. (1992), The Great Compression: The wage structure in the United States at mid-century, The Quarterly Journal of Economics 107(1), 1-34.

Gordon, R. J. \& Dew-Becker, I. (2008), Controversies about the Rise of American Inequality: A Survey, N.B.E.R. Working Paper, National Bureau of Economic Research, Inc.

Gordon, R. J. (2008), Comparing welfare in Europe and the United States, in B. Eichengreen; M. Landesmann \& D. Stiefel, ed., The European Economy in an American Mirror, Routledge,15-40.

Gosling, A. \& Lemieux, T. (2004), Labor market reforms and changes in wage inequality in the United Kingdom and the United States, in D. Card; R. Blundell \& R. B. Freeman, ed., Seeking a Premier Economy: The Economic Effects of British Economic Reforms, 1980-2000, University of Chicago Press, 275-312.

Gottschalk, P. \& Moffitt, R. (1994), The growth of earnings instability in the U.S. labor market, Brookings Papers On Economic Activity (2), 217-254. 
Green, R. K. (2008), Imperfect information and the housing finance crisis: A descriptive overview, Journal of Housing Economics 17(4), 262-271.

Green, R. \& Wachter. S. (2005), The American mortgage in historical and international context, Journal of Economic Perspectives, 19(4), 93-114.

Greenspan, A. (1996), Address: Job insecurity and technology, Conference Series; Proceedings (June), 173-181.

Guidolin, M. \& La Jeunesse, E. A. (2007), The Decline in the U.S. Personal Saving Rate: Is It Real and Is It a Puzzle?, Review (89/06), Federal Reserve Bank of St. Louis, 491-514.

Hacker, J. S. \& Pierson, P. (2010), Winner-Take-All Politics: How Washington Made the Rich Richer - and Turned Its Back on the Middle Class, Simon \& Schuster.

Hall, R. E. (1978), The stochastic implications of the life cycle-permanent income hypothesis: Theory and evidence, Journal of Political Economy 86, 971-987.

Heathcote, J.; Perri, F. \& Violante, G. L. (2010), Unequal we stand: An empirical analysis of economic inequality in the United States: 1967-2006, Review of Economic Dynamics 13(1), 15-51.

Hobson, J. A. (1909), The Industrial System: An Inquiry into Earned and Unearned Income, Longmans, Green, and Co.

Horn, G.; Dröge, K.; Sturn, S.; van Treeck, T. \& Zwiener, R. (2009), From the Financial Crisis to the World Economic Crisis. The Role of Inequality, IMK Policy Brief (10), Institut für Makroökonomie und Konjukturforschung (IMK).

Hyman, L. (2011), Debtor Nation: The History of America in Red Ink, Princeton University Press.

Iacoviello, M. (2005), Household debt and income inequality, 1963-2003, Working Papers in Economics, Boston College.

Iacoviello, M. (2008), Household debt and income inequality, 1963-2003, Journal of Money, Credit and Banking 40(5), 929-965.

IMF \& ILO (2010), The Challenges of Growth, Employment and Social Cohesion, Discussion Document, International Labour Organization and International Monetary Fund, Proceeding from the joint ILO-IMF conference held in Oslo, Norway, on September 13th 2010

Johnson, S. (2011), Did the Poor Cause the Crisis?, Project-Syndicate, http://www.projectsyndicate.org/commentary/johnson16/English.

Jones, J. M. (2007), Public: Family of Four Needs to Earn Average of \$52,000 to Get By, GALLUP News Service, http://www.gallup.com/poll/26467/public-family-four-needsearn-average-52000-get.aspx.

Katz, L. F. \& Autor, D. H. (1999), Changes in the wage structure and earnings inequality, in O. Ashenfelter \& D. Card, ed., Handbook of Labor Economics, Elsevier, 1463-1555.

Kopczuk, W.; Saez, E. \& Song, J. (2010), Earnings inequality and mobility in the United States: Evidence from social security data since 1937, The Quarterly Journal of Economics 125(1), 91-128.

Krueger, D. \& Perri, F. (2003), On the Welfare Consequences of the Increase in Inequality in the United States, NBER Working Paper, National Bureau of Economic Research, Inc.

Krueger, D. \& Perri, F. (2006), Does income inequality lead to consumption inequality? Evidence and theory, Review of Economic Studies 73, 163-193.

Krugman, P. (2010), Inequality and Crises: New York Times blog "The Conscience of a liberal" (June), http://krugman.blogs.nytimes.com/2010/06/28/inequality-and-crises/.

Kumhof, M. \& Ranciere, R. (2010), Inequality, Leverage and Crises, IMF Working Papers (268), International Monetary Fund.

Kumhof, M.; Lebarz, C.; Ranciere, R.; Richter, A. W. \& Throckmorton, N. A. (2012), Income Inequality and Current Account Imbalances, IMF Working Papers (12/08), International Monetary Fund. 
Lavoie, M. (1992), Foundations of Post-Keynesian Economic Analysis, Edward Elgar.

Lavoie, M. (2012), Consumer theory, in J. E. King, ed., The Elgar Companion to Post Keynesian Economics, 101-105.

Lee, D. S. (1999), Wage inequality in the United States during the 1980s: Rising dispersion or falling minimum wage?, The Quarterly Journal of Economics 114(3), 977-1023.

Lemieux, T.; MacLeod, W. B. \& Parent, D. (2009), Performance pay and wage inequality, The Quarterly Journal of Economics 124(1), 1-49.

Levy, F. \& Temin, P. (2007), Inequality and Institutions in 20th Century America, Working Paper (17), Massachusetts Institute of Technology, Revised June 27th 2007.

Malthus, T. (1820), Principles of Political Economy Considered with a View to their Practical Application, John Murray.

Marglin, S. (1984), Growth, Distribution and Prices, Harvard University Press.

Mazumder, B. (2005), Fortunate sons: New estimates of intergenerational mobility in the United States using social security earnings data, The Review of Economics and Statistics 87(2), 235-255.

McCoy, K. (2004), Sleeping Less Than Eight Hours a Night May Stimulate Your Appetite, Goldlite Hypnosis Institute, http://www.goldlitehypnosisinstitute.com/Sleep_Less_Making_U_Hungry.html.

Modigliani, F. \& Brumberg, R. (1954), Utility analysis and the consumption function: An interpretation of cross-section data, in K.K Kurihara, ed., Post-Keynesian Economics, Rutgers University Press.

Moffitt, R. A. \& Gottschalk, P. (2002), Trends in the transitory variance of earnings in the United States, Economic Journal 112(478), C68-C73.

Moffitt, R. A. \& Gottschalk, P. (2008), Trends in the Transitory Variance of Male Earnings in the U.S., 1970-2004, Boston College Working Papers in Economics (697), Boston College Department of Economics.

Moore, D. W. (2003), Half of Young People Expect to Strike It Rich, GALLUP News Service, http://www.gallup.com/poll/7981/half-young-people-expect-strike-rich.aspx.

Murphy, K. M.; Shleifer, A. \& Vishny, R. W. (1991), The allocation of talent: Implications for growth, The Quarterly Journal of Economics 106(2), 503-30.

Neumark, D. \& Postlewaite, A. (1998), Relative income concerns and the rise in married womens employment, Journal of Public Economics 70, 157-183.

Neumark-Sztainer, D.; Nahhan, P.; Story, M.; Croll, J. \& Perry, C. (2003), Family meal patterns: Associations with sociodemographic characteristics and improved dietary intake among adolescents, Journal of the American Dietetic Association 103, 317-22.

Noah, T. (2010), The Great Divergence, http://www.slate.com/articles/news_and_politics/the_great_divergence.html.

OECD (2008), Growing Unequal?: Income Distribution and Poverty in OECD Countries.

Olney, M. L. (1991), Buy Now, Pay Later: Advertising, Credit, and Consumer Durables in the 1920s, University of North Carolina Press.

Olney, M. L. (1999), Avoiding default: The role of credit in the consumption collapse of 1930, The Quarterly Journal of Economics 114(1), 319-335.

Palley, T. I. (1994), Debt, aggregate demand, and the business cycle: An analysis in the spirit of Kaldor and Minsky, Journal of Post Keynesian Economics 16, 371-390.

Palley, T. I. (2002), Economic contradictions coming home to roost? Does the U.S. economy face a long-term aggregate demand generation problem?, Journal of Post Keynesian Economics 25, 9-32.

Palley, T. I. (2010), The relative permanent income theory of consumption: A synthetic Keynes-Duesenberry-Friedman model, Review of Political Economy 22(1), 41-56.

Palley, T. I. (2012), From Financial Crisis To Stagnation: The Destruction of Shared Prosperity and the Role of Economics, Cambridge University Press. 
Parker, J. A. (1999), Spendthrift in America? On Two Decades of Decline in the U.S. Saving Rate, NBER Macroeconomics Annual, The University of Chicago Press, 317-370.

Philippon, T. \& Resheff, A. (2009), Wages and Human Capital in the U.S. Finance Industry: 1909-2006, NBER working paper 14644.

Piketty, T. \& Saez, E. (2006), The Evolution of top incomes: A historical and international perspective, American Economic Review 96(2), 200-205.

Piketty, T. \& Saez, E. (2007), How progressive is the U.S. federal tax system? A historical and international perspective, Journal of Economic Perspectives 21(1), 3-24.

Pollin, R. (1988), The growth of U.S. household debt: Demand-side influences, Journal of Macroeconomics 10(2), 231-248.

Pollin, R. (1990), Deeper In Debt: The Changing Financial Conditions of U.S. Households, Washington, DC: Economic Policy Institute.

Putnam, R. (2000), Bowling Alone: The Collapse and Revival of American Community, Simon and Schuster.

Rajan, R. G. (2005), Has Financial Development Made the World Riskier?, NBER Working Papers (11728), National Bureau of Economic Research, Inc.

Rajan, R. (2010), Fault Lines: How Hidden Fractures Still Threaten the World Economy, Princeton University Press.

Reich, R. (2010), Aftershock: The Next Economy and America's Future, Knopf.

Reinhart, C. M. \& Rogoff, K. S. (2010), This Time is Different: Eight Centuries of Financial Folly, Princeton University Press.

Roberts, P. (2010), How the Economy Was Lost, AK Press.

Rosen, S. (1981), The economics of superstars, The American Economic Review 71(5), 845858.

Sabelhaus, J. \& Song, J. (2009), Earnings volatility across groups and time, National Tax Journal 62(2), 347-364.

Saez, E. (2012), Striking it Richer: The Evolution of Top Incomes in the United States (Updated with 2009 and 2010 estimates).

Schor, J. B. (1998), The Overspent American: Upscaling, Downshifting, and the New Consumer, Basic Books.

Senik, C. (2005), Income distribution and well-being: What can we learn from subjective data?, Journal of Economic Surveys 19(1), 43-63.

Shiller, R. J. (2008), The Subprime Solution: How Today’s Global Financial Crisis Happened, and What to Do about It, Princeton University Press.

Slesnick, D. T. (1992), Aggregate consumption and saving in the postwar United States, The Review of Economics and Statistics 74(4), 585-97.

Slesnick, D. T. (2001), Consumption and Social Welfare: Living Standards and Their Distribution in the United States, Cambridge University Press.

Smith, A. (1776 [2009]), An Inquiry Into the Nature and Causes of the Wealth of Nations, Digireads.com.

Soman, D. \& Cheema, A. (2002), The effect of credit on spending decisions: The role of the credit limit and credibility, Marketing Science 21(1), 32-53.

Stiglitz, J. E. (2008), Toward a general theory of consumerism: Reflections on Keynes' economic possibilities for our grandchildren, in L. Pecchi \& G. Piga, ed., Revisiting Keynes: Economic Possibilities for Our Grandchildren, MIT Press, 41-86.

Stiglitz, J. E. (2009), The global crisis, social protection and jobs, International Labour Review 148, 1-2, 1-13.

Summers, L. \& Carroll, C. (1987), Why is U.S. national saving so low?, Brookings Papers on Economic Activity 18(2), 607-642.

UN Commission of Experts (2009), Report of the Commission of Experts of the President of the United Nations General Assembly on Reforms of the International Monetary and 
Financial System, Report, United Nations, New York.

Van Treeck, T. \& Sturn, S. (forthcoming): Income inequality as a cause of the Great Recession? A survey of current debates, paper prepared for the International Labour Organization (ILO) project: "New Perspectives on Wages and Economic Growth".

Vaughan, D. R. (2004), Exploring the Use of the Views of the Public to Set Income Poverty Thresholds and Adjust Them Over Time, U.S. Census Bureau.

Veblen, T. (1899 [2007]), The Theory of the Leisure Class, Oxford University Press.

Warren, E. \& Warren Tyagi, A. (2004), The Two-Income Trap, Basic Books.

Wolff, E. N. (2010), Recent Trends in Household Wealth in the United States - Rising Debt and the Middle-class Squeeze - an Update To 2007, Economics Working Paper (589), The Levy Economics Institute. 


\section{Figures and Tables}

Figure 1: Compensation of employees, personal income and disposable income, in per cent of GDP, United States, 1960-2010

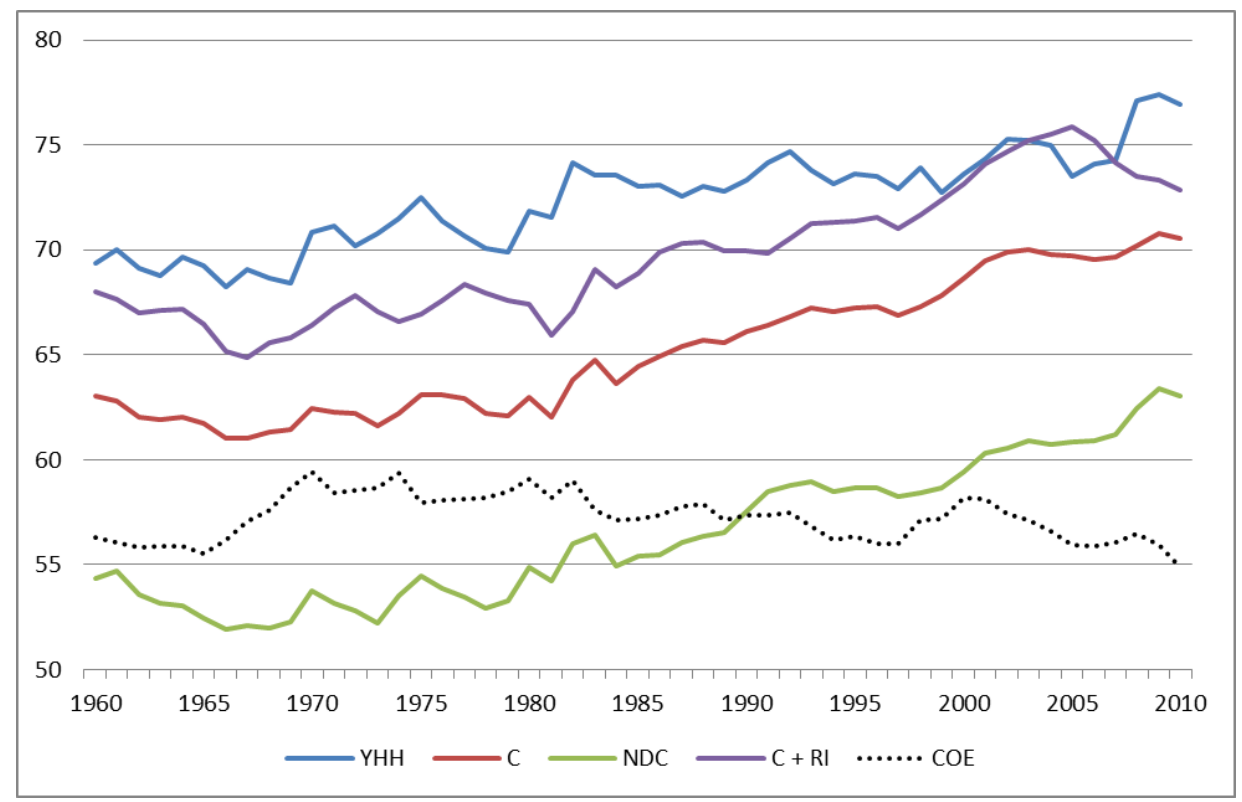

Note: $\mathrm{YHH}=$ household disposable income, $\mathrm{C}$ = private consumption, $\mathrm{RI}$ = private residential investment, $\mathrm{COE}$ = compensation of employees

Source: BEA; authors' calculations

Figure 2: Sectoral financial balances, in per cent of gross national income, United States, $1960-2010$

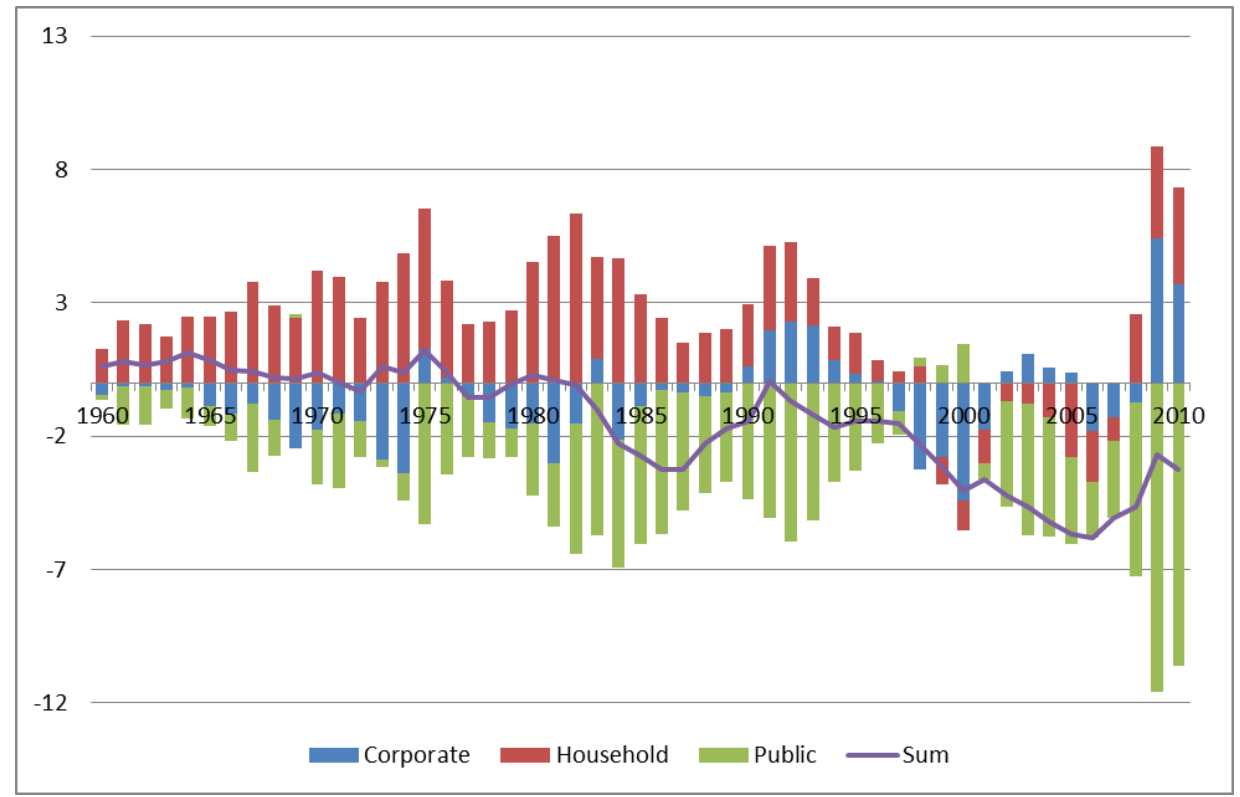

Source: BEA; authors’ calculations 
Figure 3: Top income shares, excluding realised capital gains, in per cent of total household pre-tax income, United States, 1913-2008

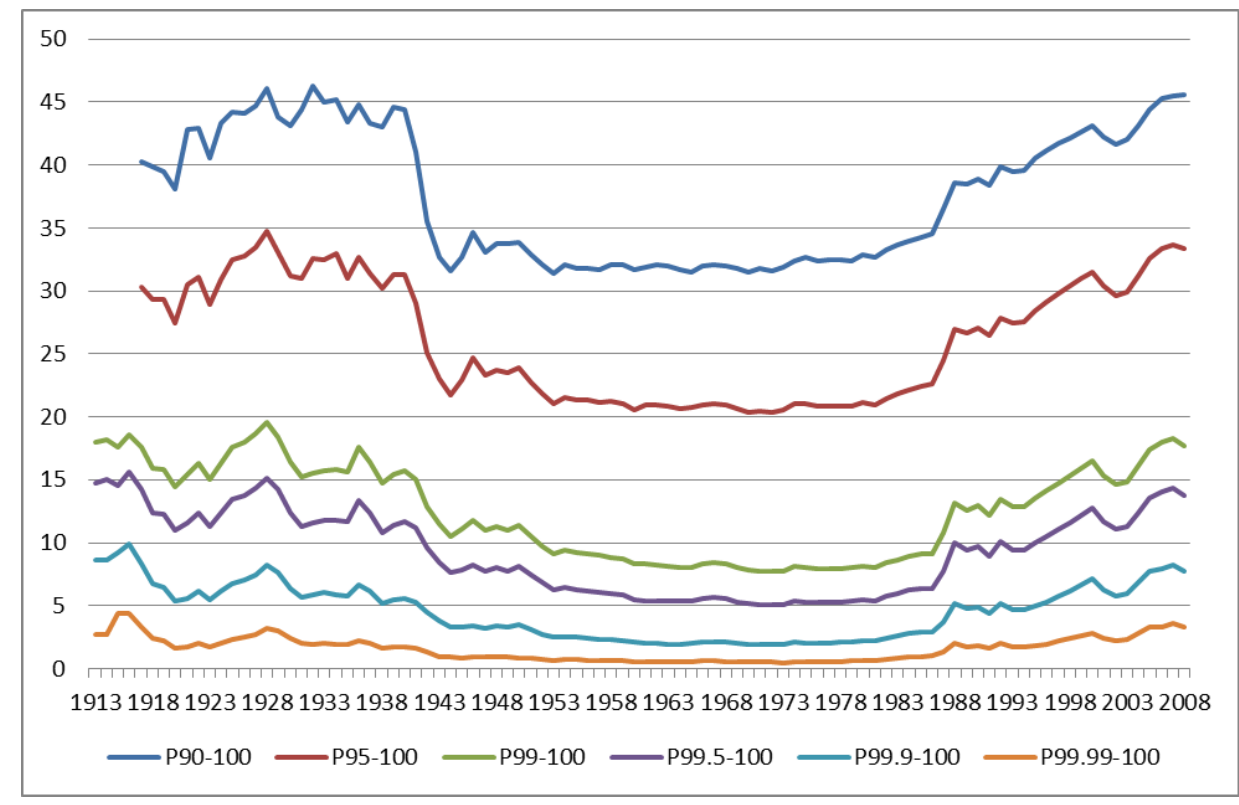

Source: http://elsa.berkeley.edu/ saez/TabFig2008.xls, based on IRS; authors’ calculations

Figure 4: Real hourly wages, United States, 1973-2009, $1979=100$

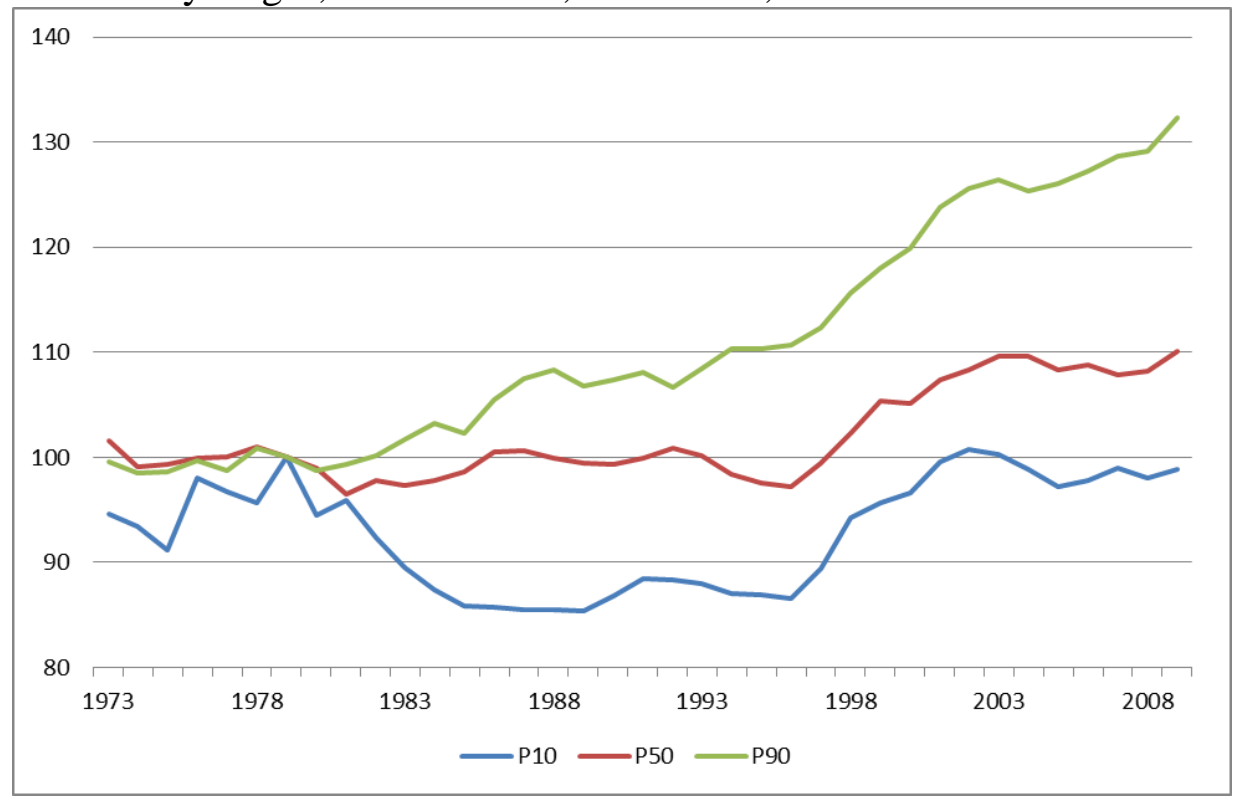

Source: http://www.stateofworkingamerica.org, based on CPS; authors' calculations 
Figure 5: Growth of real pre-tax family income, excluding capital gains, United States, 19471977 and 1977-2007

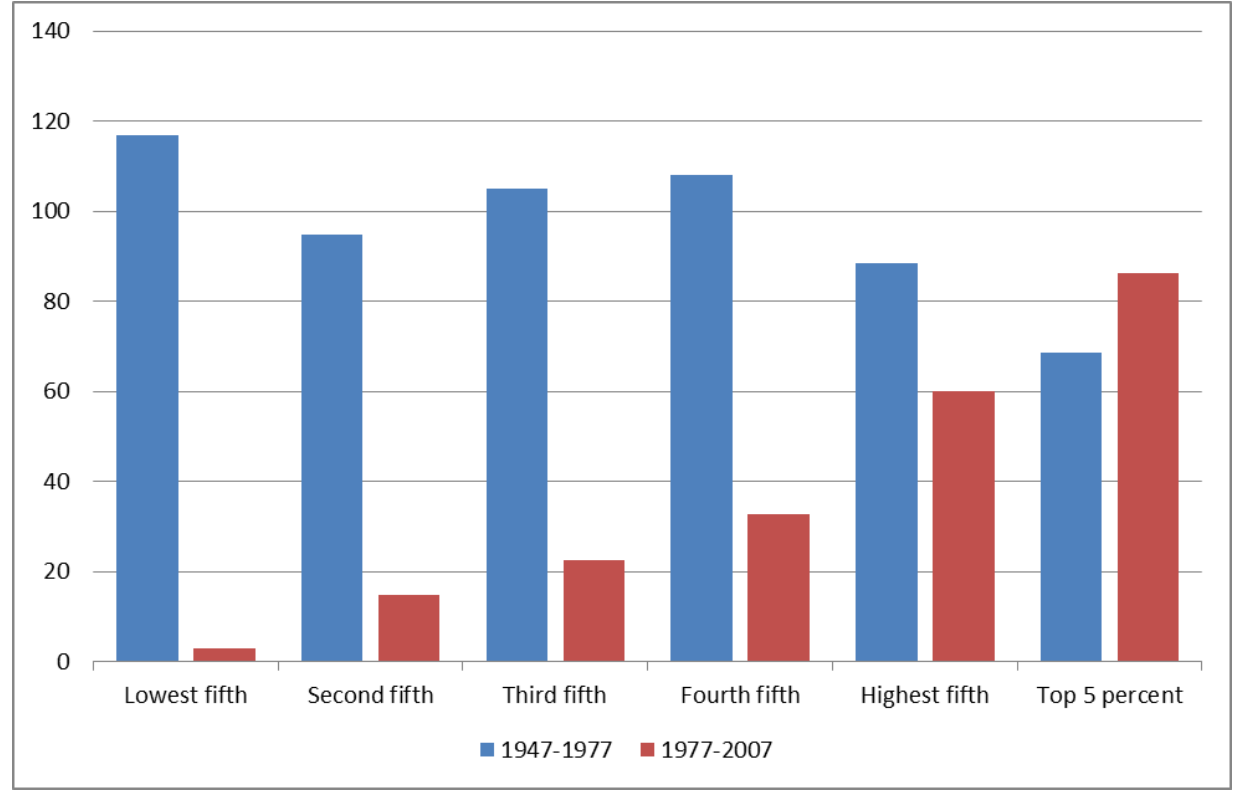

Source: http://www.stateofworkingamerica.org/files//family_income_growth.xlsx based on U.S. Census Bureau, Historical Income Tables, tables F.2, F.3, F.5 (CPS)

Figure 6: Subjective mimum income and actual income for families of four, United States, 1947-2007

a) Rates of growth of mean, median and subjective median minimum income

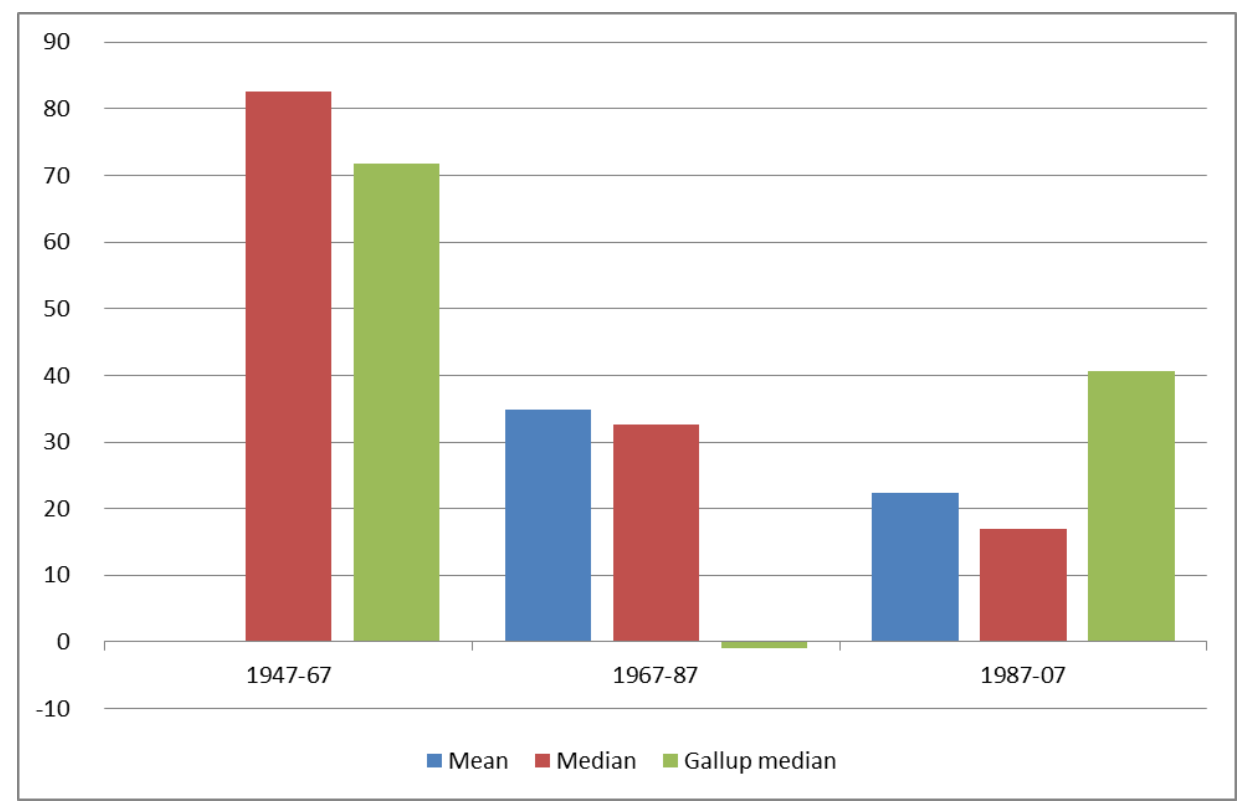

Note: Minimum income is based on responses to Gallup poll question: "What is the smallest amount of yearly income a family of four would need to get along in your local community?” Mean and median income are calculated from CPS, Historical Tables, F-8 
b) Ratio of mean and median subjective estimates of minimum income to actual median income and official poverty line

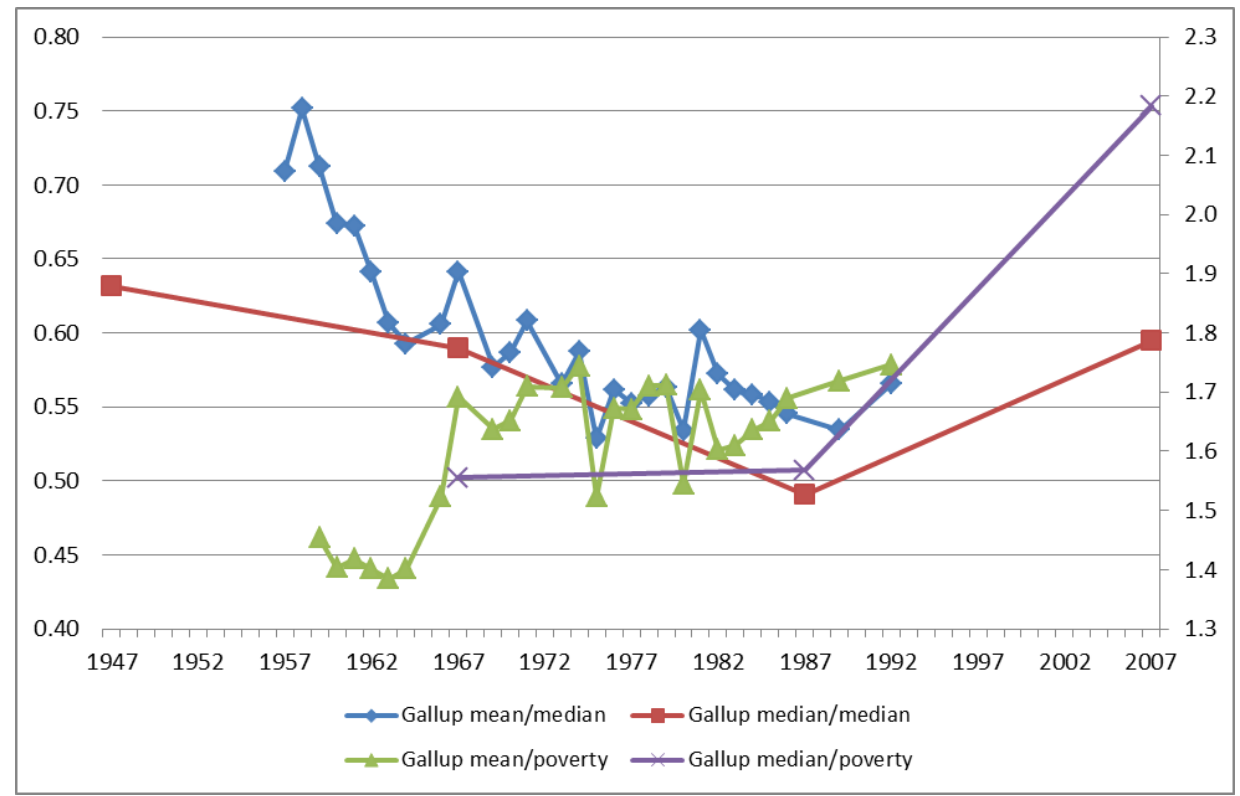

Source: Jones, 2007; OECD (2009); authors’ calculations

Figure 7: Median family income by family type, 2009 dollars, United States, 1973-2009, $1999=100$

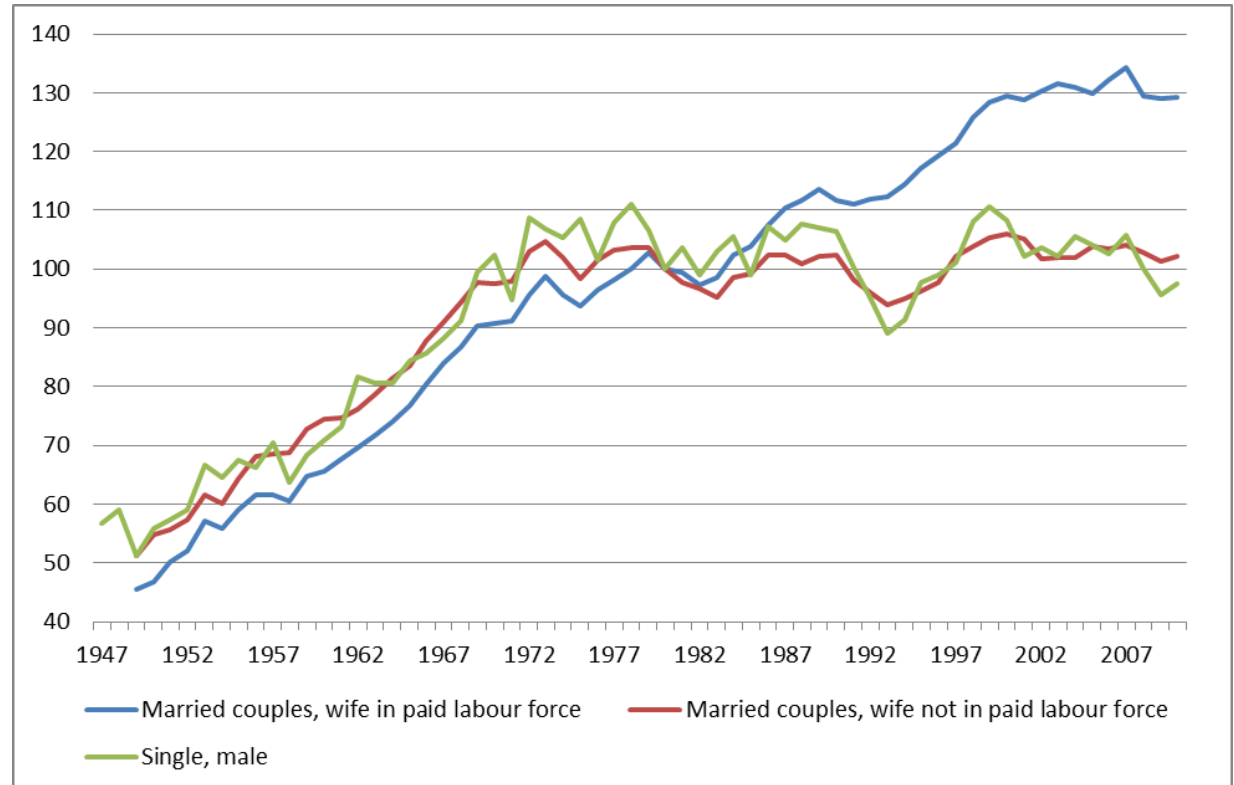

Source: CPS, Historical Tables, F-7; authors’ calculations 
Figure 8: Personal savings and debt as per cent of disposable income, United States, 19602010

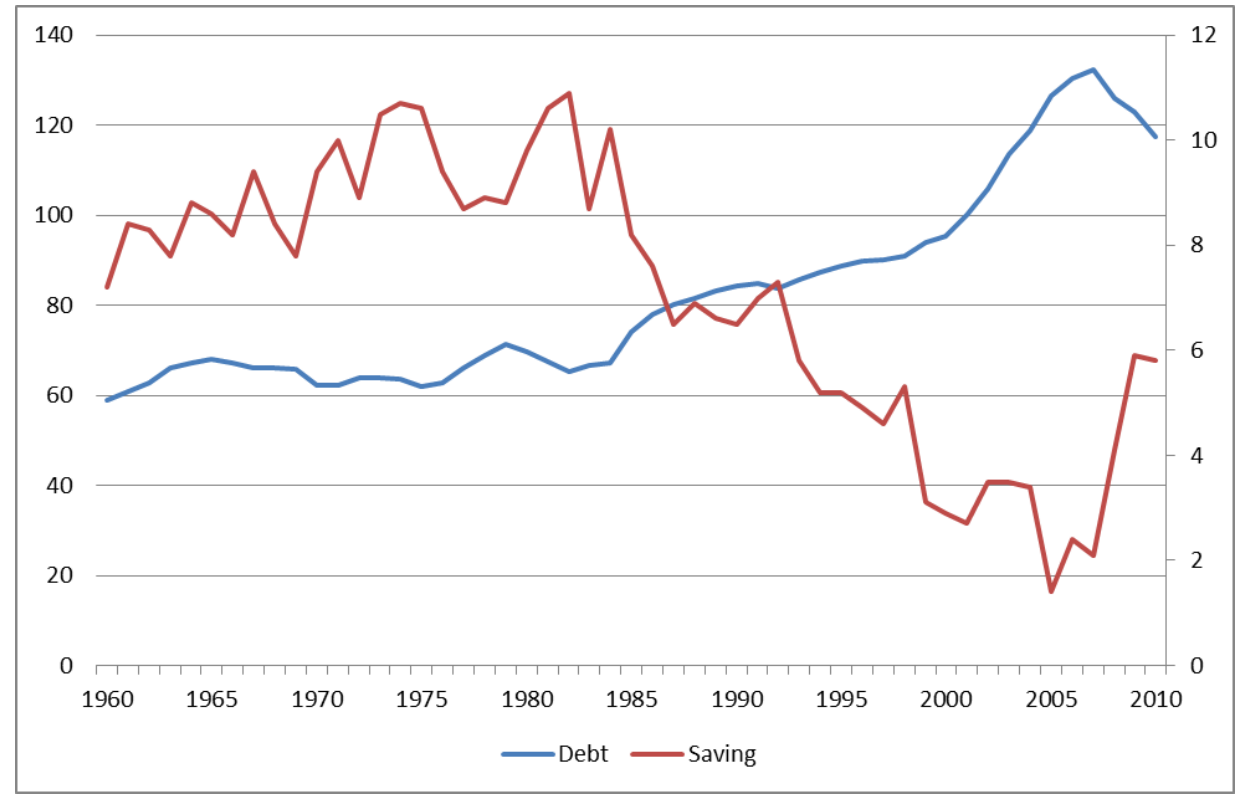

Source: NIPA, Flow of Funds; authors’ calculations

Figure 9: The personal debt-to-income ratio, in per cent, and different measures of income inequality, United States, 1960-2008, $1979=100$

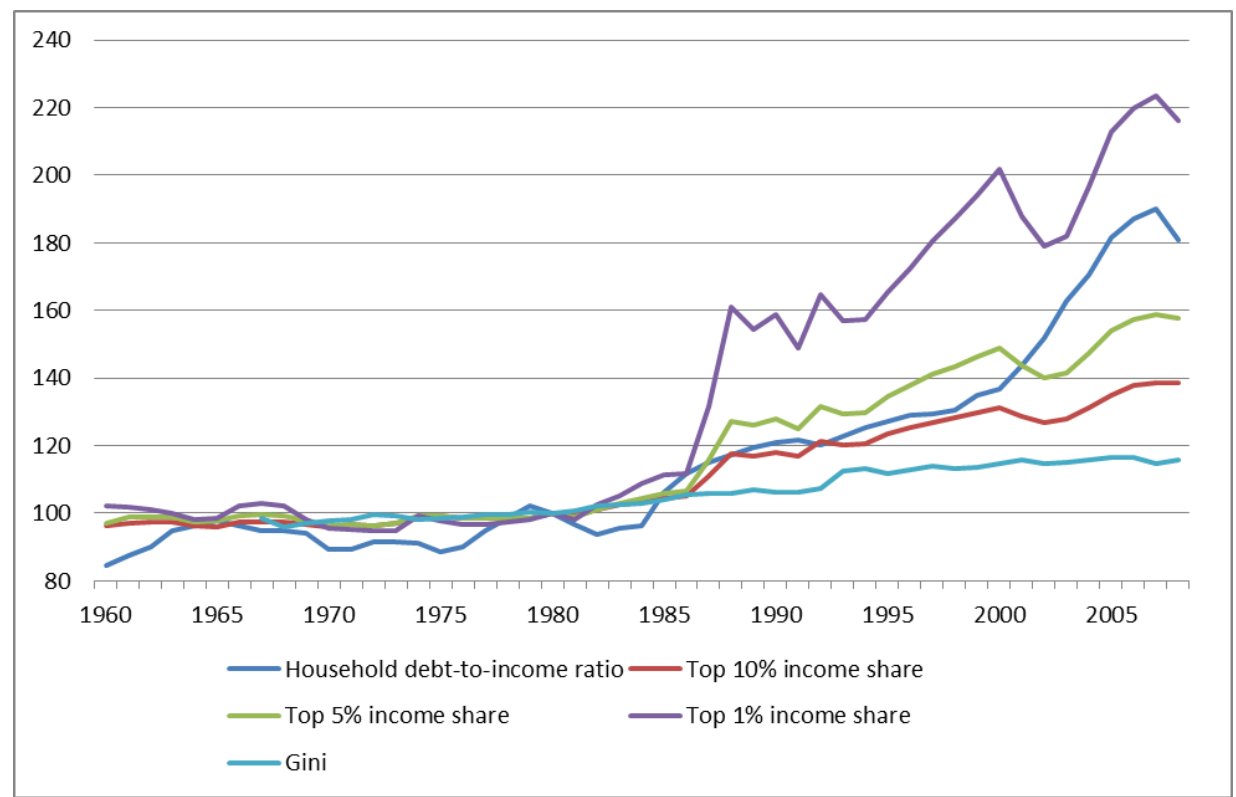

Source: Piketty and Saez (http://elsa.berkeley.edu/ saez/TabFig2008.xls), Kopczuk et al. (2010); Flow of Funds; NIPA; authors' calculations 
Figure 10: Mean household debt, in per cent of disposable income, United States, 1989-2007

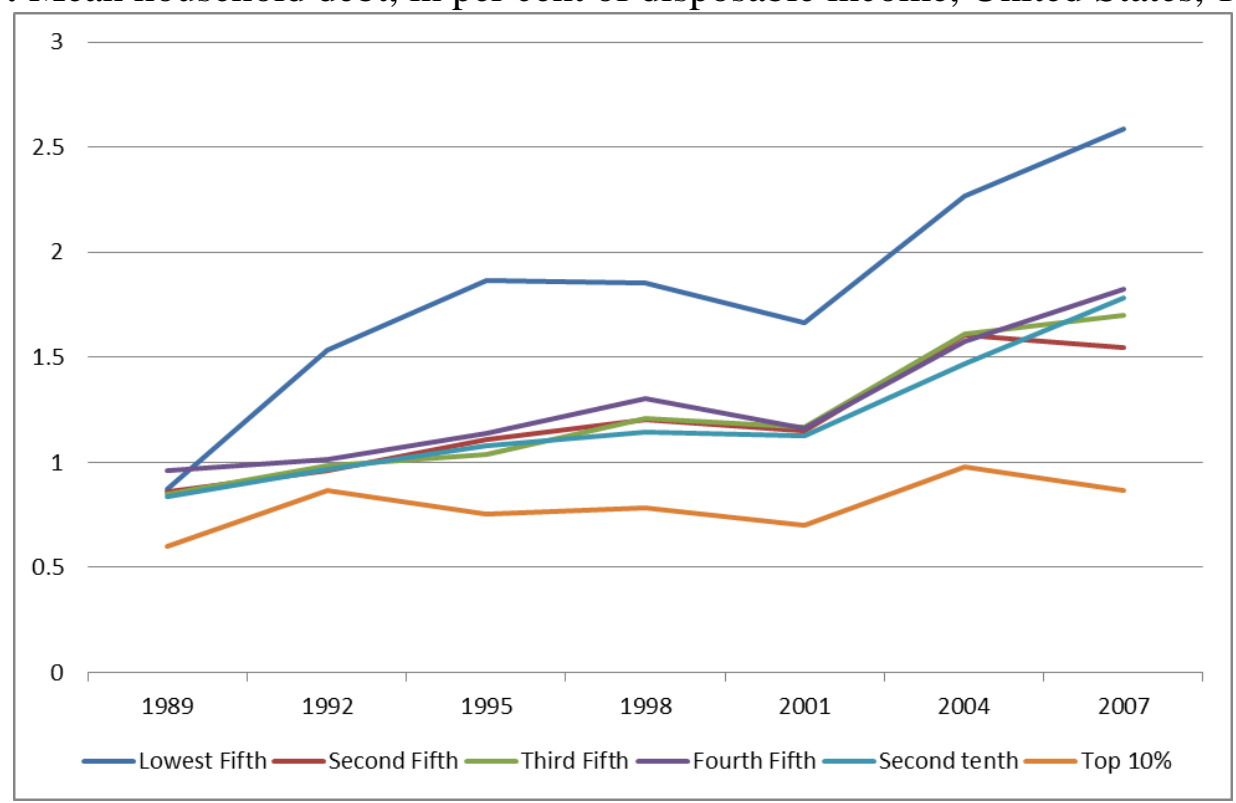

Source: Survey of Consumer Finances; authors’ calculations

Figure 11: Simulated household saving rates for a simple variant of the "expenditure cascades” model, United States, 1967-2010

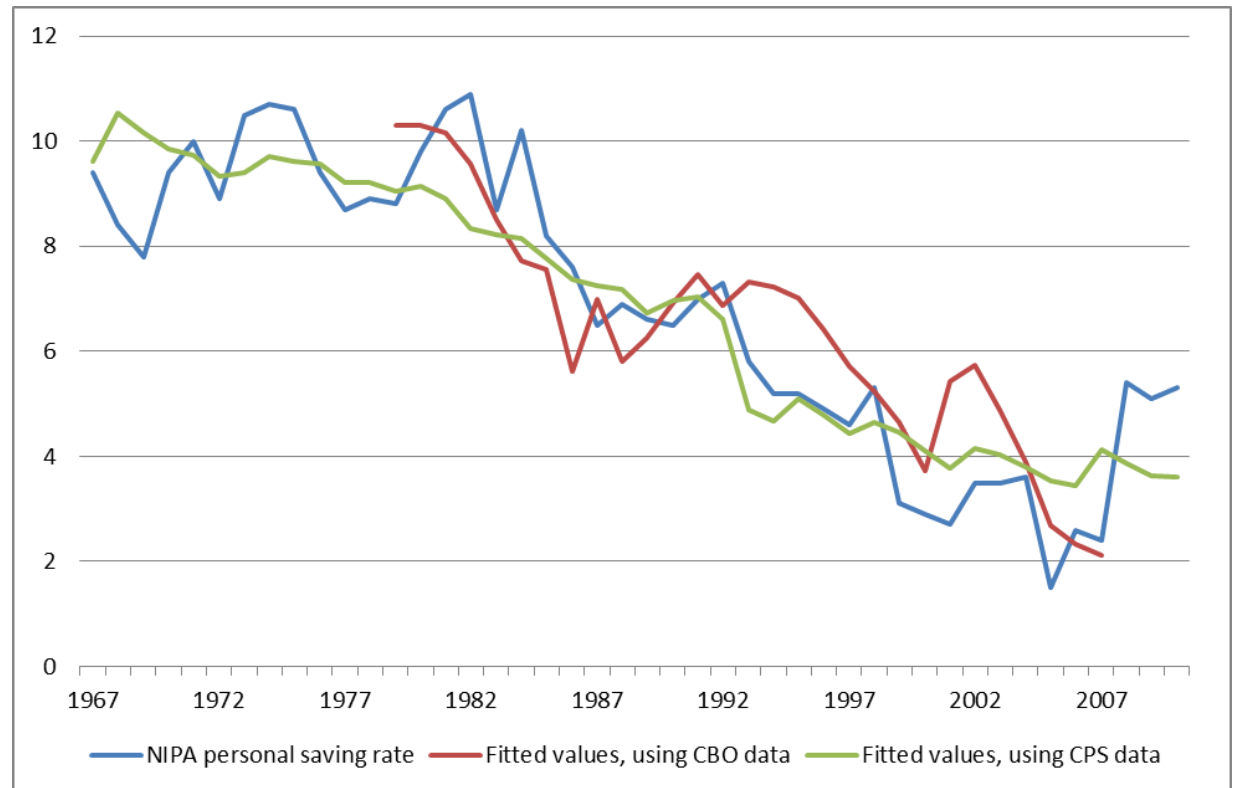

Note: We use data for household incomes by quintile taken from CBO (2010) and from U.S. Census, CPS, Table $\mathrm{H}-03$, to fit the equations $\mathrm{c}_{\mathrm{i}}=\mathrm{k}(1-\mathrm{a})(\mathrm{y})_{\mathrm{i}}+\mathrm{ac}_{\mathrm{i}+1}$, for $\mathrm{i}=1,2,3,4$, and $\mathrm{c}_{5}=\mathrm{ky}_{5}$, with $c_{\mathrm{i}}=$ consumption of household quintile $i$ and $y_{\mathrm{i}}=$ income of quintile $i$. We choose $k=0.7$ and $a=0.5$ for the CBO data, and $k=0.65$ and $a=0.55$ for the CPS data.

Source: Authors' calculations 
Table 1: Per cent who expect to be rich, compared by age, United States, January 2003

\begin{tabular}{|c|c|c|c|c|}
\hline & $\begin{array}{c}\text { Very/somewhat } \\
\text { likely to be rich } \\
\mathbf{( \% )}\end{array}$ & $\begin{array}{c}\text { Already rich } \\
\mathbf{( \% )}\end{array}$ & $\begin{array}{c}\text { Amount of as- } \\
\text { sets to be rich } \\
\text { (median dol- } \\
\text { lars) }\end{array}$ & $\begin{array}{c}\text { Amount of } \\
\text { household in- } \\
\text { come to be rich } \\
\text { (median dol- } \\
\text { lars) }\end{array}$ \\
\hline Overall & 31 & 2 & $1,000,000$ & 122,000 \\
\hline Aged 18-29 & 51 & 0 & 463,000 & 100,000 \\
\hline Aged 30-49 & 36 & 1 & $1,000,000$ & 200,000 \\
\hline Aged 50-64 & 22 & 4 & 764,000 & 100,000 \\
\hline Aged 65+ & 8 & 2 & 500,000 & 74,000 \\
\hline Income $<\$ 30 K$ & 21 & 1 & 500,000 & 100,000 \\
\hline $\begin{array}{c}\text { Income \$30K- } \\
\text { \$50K }\end{array}$ & 21 & 0 & \multirow{2}{*}{$1,000,000$} & 200,000 \\
\hline $\begin{array}{c}\text { Income \$50K- } \\
\mathbf{\$ 7 5 K}\end{array}$ & 38 & 3 & & \\
\hline Income $>$ \$75K & 51 & 3 & \\
\cline { 1 - 2 }
\end{tabular}

Note: Note: The table reports answers to the following question: Looking ahead, how likely is it that you will ever be rich? Would you say it is - very likely, somewhat likely, not very likely, or not likely at all? Median and mean net worth in 2004 were, respectively, \$85,500 and \$472,500, and the number of households with net worth of $\$ 1,000,000$ or more was 6,466 , i.e., 5.8 per cent of all households (see Wolff, 2010, p. 43, based on the Survey of Consumer Finances). Median and mean household income in 2003 were, respectively, \$43,318 and \$59,067 (see U.S. Census, Table H-5). The mean income of the highest quintile of all households in 2003 was $\$ 147,078$ (see U.S. Census, Table H-3).

Source: Moore (2003)

Table 2: Perceived likelihood of getting rich, United States, 1990, 1996, 2003

\begin{tabular}{|l|c|c|c|c|c|c|}
\hline & $\begin{array}{c}\text { Very like- } \\
\text { ly }\end{array}$ & $\begin{array}{c}\text { Somewhat } \\
\text { likely }\end{array}$ & $\begin{array}{c}\text { Not very } \\
\text { likely }\end{array}$ & $\begin{array}{c}\text { Not at all } \\
\text { likely }\end{array}$ & $\begin{array}{c}\text { Already } \\
\text { rich }\end{array}$ & $\begin{array}{c}\text { No opin- } \\
\text { ion }\end{array}$ \\
\hline 2003 Jan & 10 & 21 & 36 & 30 & 2 & 1 \\
\hline 1996 Apr & 10 & 23 & 37 & 27 & 1 & 2 \\
\hline 1990 May & 9 & 23 & 32 & 35 & $*$ & 1 \\
\hline
\end{tabular}

Note: The table reports answers to the following question: Looking ahead, how likely is it that you will ever be rich? Would you say it is - very likely, somewhat likely, not very likely, or not likely at all?

Source: Moore (2003) 
Publisher: Hans-Böckler-Stiftung, Hans-Böckler-Str. 39, 40476 Düsseldorf, Germany Phone: +49-211-7778-331, IMK@boeckler.de, http://www.imk-boeckler.de

IMK Working Paper is an online publication series available at: http://www.boeckler.de/imk 5016.htm

ISSN: $1861-2199$

The views expressed in this paper do not necessarily reflect those of the IMK or the Hans-Böckler-Foundation.

All rights reserved. Reproduction for educational and non-commercial purposes is permitted provided that the source is acknowledged. 